\title{
Boundary Stones and the Rebellion of Nature
} Reflections on a Presumed Statue of Terminus in a Roman Sculpture Garden

\author{
Charles Burroughs \\ Smith Professor of Humanities, Department of Classics and Art History \\ (emeritus), Case Western Reserve University, Cleveland, OH, USA, and \\ Adjunct Professor of Art History, Department of Art History, State University \\ of New York at Geneseo, Geneseo, NY, USA \\ burroughs@geneseo.edu
}

\begin{abstract}
Boundaries demarcate property throughout European history, though the utopian dream of terrain without boundaries recurs, not least in association with the figure of the free-roaming god Pan. Ancient Rome had a god of boundaries, Terminus, associated by Horace with venerable, quasi-natural landscapes of human occupation. In Renaissance culture, Terminus is represented as a hybrid figure-part human; part lithic; often incorporated into architecture. This essay identifies a composite object in a Roman sculpture collection, noted for figures of Pan, as a model for Erasmus's widely divulged emblem of Terminus, featured in images by major artists. Initially identifying himself with Terminus's resistance to divine authority, Erasmus met with criticism for arrogance. In response, he drew on Horace's ethically colored evocation of Terminus, now in connection with the ultimate boundary, that between life and death, as appears in Hans Holbein's moving design for a monument to the humanist.
\end{abstract}

\section{Keywords}

boundaries - Terminus - Pan - Horace - Renaissance - Erasmus

\section{$1 \quad$ Limits and Boundaries}

Ut pictura poesis: Horace's pithy phrase in his Art of Poetry (Ars Poetica or Epistula ad Pisones, 361 ) has reverberated in Western cultural history like no other, 
energizing debates about the so-called paragone. ${ }^{1}$ At the beginning of the work, however, Horace betrays some skepticism about the 'sisterhood' of text and image ${ }^{2}$ he imagines an art exhibition in which a painting of a monstrous hybrid creature - a 'grotesque' avant la lettre ${ }^{3}$ —elicits deserved ridicule. Presumably this comes especially from writers, in spite of the objection, not in Horace's voice, that artists and writers have the same license to innovate, even beyond limits set by nature. ${ }^{4}$ The account of the composite creature, which turns out to be a kind of mermaid, seems deliberately to challenge visualization, ${ }^{5}$ but in any case a key characteristic of the Art of Poetry is a certain evasiveness and ambiguity — here about boundary crossing between media. ${ }^{6}$ Coursing through Horace's poetic imagination as well as his moral thinking, however, is a larger concern with boundaries, literal and metaphorical. A key concept in this discursive field is terminus - literally 'boundary stone'- that came to have an important nachleben in the Renaissance, part of which I explore in this essay.

Like many authors of the Augustan age, Horace found inspiration in the ancient idea of the Golden Age; his major reference to the concept (Epode 16) imagines a utopian place, beyond the borders of the real world, which provides respite from the dangers and troubles of the time. As already formulated by Hesiod (Works and Days, 42-46) at the dawn of European literature, the Golden Age is normally situated irrevocably in the past, at least until Augustus's reforms and approving responses to them, most notably and influentially Virgil's Fourth Eclogue (Horace's dream of escape, needless to say, predates Augustus's victory). ${ }^{7}$ A key characteristic of the mythical Golden Age was commonality; primitive humans drew sustenance from the natural world as they found it, with no need to work the land or, as a corollary, to impose boundaries upon it. In the state of nature, in other words, the divisions of land according to

1 In the vast literature on the paragone, see now Hessler, Zum Paragone; Baader, Im Agon der Künste; Burroughs, Raphael and the Paragone. On the character of Horace's text (a letter rather than a treatise) and the puzzles of its opening, see Rudd, Horace Epistles, Book II, 19, 34-37; Ferriss-Hill, Horace's Ars Poetica, 1-35, 39-46; and P.A. Miller, Horace, 9-15.

2 The reference is to Hagstrum, The Sister Arts.

3 On Horace's apothegms in relation to the Renaissance fashion for grotesques, see now Hansen, The Art of Transformation, 73-75.

4 Ars Poetica (Epistula ad Pisones) 9-10: 'pictoribus atque poetis/ quidlibet audendi semper fuit aequa potestas'. On the complexities, even traps, of the opening of the Art of Poetry, see Ferriss-Hill, Horace's Ars Poetica, 39-46.

5 Ferriss-Hill, Horace's Ars Poetica, 39-43.

6 In an account of the poem as Socratic and full of irony, P.A. Miller, Horace, 9, characterizes the Art of Poetry as 'rambling and disjointed'.

7 Levin, The Myth of the Golden Age in the Renaissance; Houghton, 'Virgil's Fourth Eclogue'; Zorzi, 'Hesiod in the Byzantine and Early Renaissance Periods'. 
proprietorial rights did not exist. Though not a practical call to action, Thomas More's Utopia (1516) famously evokes the possibility of a reinstitution of this state of affairs, ultimately drawing on the transcendence of property advocated by Plato in the Republic, at least for the ruling elite of his 'beautiful polis'. As Dominic Baker-Smith puts it, 'By making his Utopians adopt a communality of possessions More liberates them from the passions generated by acquisition and loss; by the same token, they are relieved of the whole ideological burden which distorts European society'.

In his didactic poem on agriculture, the Georgics, Horace's contemporary Virgil, as Peter Garnsey has noted, ambiguously 'conjures up an idyllic world in which commonality was practiced, but he does this within a poem ... whose theme is the virtue of the small landowner and the dignity of agriculture.9 In Virgil's earlier pastoral poems, the Eclogues, the attachment to land is a major theme, especially as expressed in the laments of peasants dispossessed as a result of Augustus's policies. Countering this bleak picture, however, Virgil's celebration in the Fourth Eclogue of the return of the Golden Age, under Augustus, draws on a long tradition of appeal to a 'soft primitivist' myth of an era without toil and pain, ${ }^{10}$ in which it may be assumed land division is yet to occur.

Augustan authors imagine, then, two kinds of ideal existence. One is the utopian notion of a Golden Age, during which men live 'like gods'; the other is the idea of a traditional worked landscape, in which humans live in harmony with their surroundings, often in a period imagined (e.g., by Horace, Odes 3.3346) as preceding, and better than, the decadent present. ${ }^{11}$ In the Eclogues, Virgil laments the confiscations that were disrupting peasant life, though perhaps (he does not specify) without altering the pattern of occupation of the land, as opposed to the identity of the people concerned. But this was an era when the traditional organization of terrain and assumptions about it underwent a more profound challenge through the replacement of small proprietors by latifundia worked by gangs of slaves for absentee masters, a system of exploitation both of men and land memorably denounced by Pliny the Elder (Natural History 18.4 and 35), less than a century after Horace's lifetime, as 'destroying' Italy. ${ }^{12}$ Such changes in land use seem to lie behind Horace's complaints, dis-

8 Baker-Smith, 'Thomas More', in The Stanford Encyclopedia of Philosophy, n.p. (Online).

9 Garnsey, Thinking about Property, 110.

10 Lovejoy and Boas, Primitivism and Related Ideas in Antiquity, 7-11, famously distinguish a soft primitive world of innocent leisure from a hard world of incessant toil and pain. See also Panofsky, 'Et in Arcadia Ego', 297.

11 Harrison, 'Town and Country', 239.

12 'Latifundia perdidere Italian' (latifundia have ruined Italy); Lomas, Roman Italy, $338 B C-A D$ 
cussed below, about the hubristic uprooting of boundary markers, which had seemed almost part of the 'natural' landscape, a concern related to a more elevated, metaphorical level of discourse about boundaries - and more generally limits-embracing the moral life. The observance of limits to appetite and ambition was a key element of ethical theory in the classical tradition, especially in light of the need to come to terms with human mortality, a limit that was indubitably part of a natural order of things. It is a major theme of Horace's poetry. ${ }^{13}$

The Roman attitude to the rural world was complex and inconsistent, as we have seen, even in the work of Virgil, its great poet. ${ }^{14}$ However, in myth and poetry, as well as in cult practices, traditional rural landscapes and their inhabitants assumed a 'natural' character, in part through sharing their fields and forests with a range of divine and semi-divine beings, forming a kind of continuity of rural existence..$^{15}$ In Ovid's Metamorphoses, in particular, confusions abound between natural and man-made settings, with reverberations throughout Western cultural history. ${ }^{16}$ The goat god Pan, patron both of shepherds and wild places, embodies the permeability of the boundary between human and animal life, and he roams between the pastoral world and the deep forests and rugged mountains.${ }^{17}$ Drawing on his own experience as rural proprietor, Horace (Odes 3.18) addresses a poem to Faunus, the Latin Pan, divine protector of crops and animals, affectionately evoking popular festivity in a rustic world that, at least on special occasions, can assume an almost utopian quality. Thanks to Faunus, the lambs on Horace's estate can gambol unthreatened in the presence of a wolf, while Faunus himself moves through the landscape in disregard of Horace's and presumably all artificial boundaries (l. 2, 'per meos fines'). ${ }^{18}$ For Christian readers of Horace, the poem surely brought to mind the line in Isaiah (65:25; see also 11:6-7): 'The wolf and the lamb shall feed together'. Certainly the Christian appropriation, over centuries, of Virgil's Golden Age prophecy in

200, 148-149. In his manual of farming, the Republican statesmen Cato assumes prevalent slave labor on the land; see Joshel, Slavery in the Roman World, 57.

13 Horace, Art of Poetry, 68, 'mortalia facta peribunt'. On the implications of this, see FerrissHill, Horace's Ars Poetica, 67-68.

14 See now Armstrong, Vergil's Green Thoughts.

15 On the complex issue of animism in Virgil, see Armstrong, Vergil's Green Thoughts, 62-70.

16 Hansen, Art of Transformation, 192-196. Barolsky, Ovid and the Metamorphoses of Modern Art, covers the whole trajectory.

17 Wiseman, Myths of Rome, 76.

18 Also Lucretius, De rerum natura (4.580-589) mentions belief in boisterous fauns (plural) and Pan who play music in the night; Wiseman, Myths of Rome, 76 . 
Eclogue 4 is too well known to require comment. ${ }^{19}$ Even Pan received a Christian gloss in the Renaissance, not least thanks to the Neo-Platonist reception of the Orphic Hymn to Pan and late ancient conceptions of Pan as 'cosmological god of the universe' - in other words, a deity that transcends all boundaries. $^{20}$

In sixteenth-century Rome and its environs, the distinction of nature and culture was often elusive, sometimes by design: ${ }^{21}$ lush spring-rich gardens abounded, as did moldering ruins supporting rapacious fig trees and clambering goats in a landscape in which, in Joachim Du Bellay's eloquent line (published in 1558), only the flow of the Tiber was the same as in Antiquity and anything solid could dissolve. ${ }^{22}$ The gardens of the elite were ornamented, or rather peopled, by statuary, including hybrid figures such as Pan/Faunus or satyrs, expressive of instinctual behavior and the merging of human and animal elements, and so suitable to places of informal recreation..$^{23}$ Among these hybrid figures an important type was composed of a post topped by the upper part of a human body. Such 'terms' abounded in sixteenth-century visual culture, most notably in Michelangelo's designs for the tomb of Julius II and Raphael's Stanza dell'Incendio, where they frame the window embrasures opening to the outside world and connecting the imagery in the room to the realm of action beyond (Fig. 1). ${ }^{24}$ At the same time they apparently refer to the origin of the motif itself, the ancient Roman god of boundaries, Terminus. In this essay I explore the context and implications of a previously unnoticed figure of Terminus in Rome, proposing a connection between it and the most famous representation of Terminus in the early sixteenth century: the emblem of Erasmus of Rotterdam, a

19 Houghton, 'Virgil's Fourth Eclogue', 180, comments on Poliziano's late fifteenth-century account of the relationship: 'The fact that the Christianizing construal of the ... poem looms so prominent in Poliziano's précis ..., demonstrates how inseparable Virgil's celebration of the consulship of Pollio had become from the associations conferred on it by centuries of Christian assimilation'.

20 Robert, 'Pan', 496. Whatever else it may mean, Signorelli's painting The Kingdom of Pan is informed by cosmological conceptions of Pan and by ideas about the origins of art in nature; Barolsky, The Faun in the Garden, 94-97.

21 On the 'Third Nature' that arises from both nature and culture together, see Lazzaro, The Italian Renaissance Garden, 9. See also Hansen, Art of Transformation, 219-261; Beck, 'Gardens as a "Third Nature".

22 Du Bellay, Les Antiquitéz de Rome, 3.11: 'Le Tibre seul, qui vers la mer s'enfuit, Reste de Rome'. The obvious paradox is that the only stable object in Rome is a river that always flows. See Barkan, Unearthing the Past, xxviii-xix.

23 MacDougall, Fountains, Statues, and Flowers, 115.

24 Watson, 'On a Window in Parnassus', 127-148. I refer to my own discussion in Burroughs, 'Raphael and the Paragone'. 
great admirer of the poetry of Horace, especially for his profound if not entirely consistent musings on the motif of the boundary or limit both in life and in art.

\section{The Terminus Motif and the Fashion for Hybridity}

In any account of boundary crossing in Renaissance visual culture, the fashion for grotteschi must take an important place. In grotesque imagery every kind of 'natural' distinction was open to challenge, along with the rules of architecture as they were gradually becoming established through laborious study of Vitruvius and the remains of the ancient built environment (Fig. 2); ${ }^{25}$ in language echoed, as we saw, by Horace in the Art of Poetry, Vitruvius (De architectura 7.5) himself denounced such 'monstrous' offenses against architectural propriety in his own day. ${ }^{26}$ Fundamental in the Vitruvian approach was the appeal to the human body, not without differences of gender (De arch. 4.1.7), as a legitimating source of proportion and even form. Less abstractly, in a passage that met with particular enthusiasm in the Renaissance, Vitruvius (De arch. 1.4.8-5.11) also recommended the incorporation of the human body in buildings in place of columns. For Vitruvius, such figures have one connotation only, to shame and punish an enemy; accordingly, Vitruvius mentions both the women of the city of Carya, as he calls it, pressed into architectural servitude as a memorial of their city's treachery (hence the term 'caryatid' for a female support figure), and the figures of dishonored male Persian captives. ${ }^{27}$

Whether through literary sources or physical remains, however, Renaissance antiquarians and artists knew of several ancient examples of support figures that did not accord with the punitive function of Vitruvius's account. ${ }^{28}$ Raphael studied the head of a remaining caryatid from Augustus's Forum in Rome; placing it in an imaginary reconstruction of Vitruvius's support figures, he surely emphasized formal likeness rather than semiotic correspondence (Fig. 3). ${ }^{29}$ In his encyclopedic account of ancient statuary, well known in the Renaissance, Pliny the Elder (Natural History 36.4) notes the existence in Rome of several works by the celebrated sculptor Praxiteles. These included a set of cary-

25 Hansen, Art of Transformation, 252, refers aptly to 'a sfumato of stone'.

26 On Vitruvius, see Gombrich, The Sense of Order, 10. On the positive reception of such monsters in the Renaissance, see Payne, 'Mescolare, composti and Monsters'.

27 Rykwert, The Dancing Column, 123; Nichols, Author and Audience, 30-32.

28 The point is made by Dietrich-England, Sockelzone, 250.

29 Christian, 'Raphael's Vitruvius and Marcantonio Raimondi’s Caryatid Facade', 74-75. 
atids, displayed along with Dionysian figures, ${ }^{30}$ which were perhaps identified as Spartan Maenads, along the lines of certain statues at Athens. ${ }^{31}$ The latter were perhaps related to the maidens who, according to Pausanias (Description of Greece 3.320), performed a ritual dance in honor of 'Karyatid' Artemis in Caryae, probably the city of the Vitruvius passage. ${ }^{32}$ Though they sometimes appear to be simply fantastic, caryatids and similar figures known or known of in the early sixteenth century exhibited a remarkable range of associations, if not meaning, ${ }^{33}$ lending themselves to incorporation in a range of contexts, from frivolous to tragic. Further, anthropomorphic supports enlivened works of architecture, intensifying the effect of presence. ${ }^{34}$

\section{Boundary Marking in the Stanza d'Eliodoro}

Some of the most inventive support figures are surely those of Raphael in the Stanza d'Eliodoro (Fig. 1), in the dado zone beneath the great frescoes of divine interference in historical events; apparently they represent practical and civic arts and occupations, or their results (one carries a large cornucopia). ${ }^{35}$ Most are caryatids or atlanti-that is, female or male human figures in the place of columns; but on two walls, anomalous figures flank the window embrasures that interrupt the frescoed surface and extend down to a stone bench. Consisting of a tapered post below the torso, they exemplify the hybrid figure, noted above, of the term, which combines both architectonic and human components and was ubiquitous in sixteenth-century visual culture. ${ }^{36}$

Each of the four terms is vertically cut off by a window, but Raphael did not simply divide a single term into two; instead, each window is framed by contrasting half terms, one older and bearded, and one youthful and, at least in one case, female. The terms share some of the active affect of the full-bodied sup-

$30 \quad$ Plommer, 'Vitruvius and the Origin of Caryatids', 98.

31 Corso, The Art of Praxiteles, 164-165, argues (165 n. 300) that these 'caryatids' were not support figures, but this is certainly not an obvious implication of Pliny's text.

32 Plommer, 'Vitruvius and the Origin of Caryatids', 98, quotes Pausanias's only use of the term 'caryatid' as epithet of the goddess Artemis in the Caryan cult (Description of Greece, 3.10.7).

33 Morel, 'L' art des grotesques et les marges de la nature'.

34 Echinger-Maurach, Studien zu Michelangelos Juliusgrabmal, 17.

35 C.L. Frommel, 'Cariatidi, telamoni e termini', 127, posits a link between the terms and the scenes above, notably the Liberation of St. Peter, as symbols of resurrection. If so, the correspondences are not consistent.

36 See now Julien, 'Termes, atlantes, et caryatides'. 
port figures but lack attributes, leaving their signifying capacity open to question, though one is a satyr, suggesting a gesture toward the gardens of Rome or perhaps the wilder country beyond. ${ }^{37}$ Indeed, Flavia Dietrich-England has suggested that the terms' position on the window walls dramatizes their liminal position at the interface between interior and exterior space. ${ }^{38}$ If so, this evokes, as we saw, Raphael's device in the earlier Stanza della Segnatura of a paragone of sorts between a fictive landscape on the wall — the representation of Mount Parnassus peopled by poets and muses and presided over by Apollo (Fig. 4) and the exterior physical landscape of the Belvedere courtyard, ideally visible through the 'window in paradise' (usually closed, as it is in the photograph) and beyond that the sculpture garden with the famed statue of the god, the Apollo Belvedere. ${ }^{39}$

If indeed the terms in the Stanza d'Eliodoro mark a threshold and signpost a virtual path beyond, they allude to an ancient Roman tradition not addressed by Vitruvius but essential in the organization of the wider landscape and its legitimation. ${ }^{40}$ In the ancient Roman countryside, the practical device of a terminus (whether a stone, post, or gnarly tree trunk) marked the boundary between landholdings and confirmed patterns of spatial organization. As we learn from literary sources, notably Ovid's account of Terminus's festival, the Terminalia (Fasti 2.638-683), a boundary stone might also serve as a cult site, evoking the presence in the landscape of the powerful god of boundaries, Terminus himself. ${ }^{41}$ As perhaps was appropriate for a prescriptive marker in the Roman rural landscape, Terminus was aniconic, 'never represented in human style. ${ }^{42} \mathrm{His}$ iconographic tradition was an innovation of the Renaissance, when, as discussed below, the god assumed partly anthropomorphic form, usually with a torso and head atop a more or less cubic block.

37 On the possible iconography of the terms, see C.L. Frommel, 'Cariatidi, telamoni e termini', 127, emphasizing the link between the terms, which echo or imitate similar figures on Michelangelo's tomb of Julius II, and the scenes above, notably the Liberation of St. Peter, as symbols of resurrection.

38 Dietrich-England, Sockelzone, 169.

39 Jones and Penny, Raphael, 68; Watson, 'On a Window in Parnassus', 142.

40 Dietrich-England, Sockelzone, 167.

41 Terminus does not appear in the index of the encyclopedic survey of ancient imagery known in the Renaissance; Bober and Rubinstein, Renaissance Artists and Antique Sculpture. Boundary stones from the Roman pomerium (sacred boundary) exist now, but there seems to be no reference to them on the part of Renaissance antiquarians; Beard and North, Religions of Rome, 2:93.

42 Beard and North, Religions of Rome, 2:3. 
'Terms' used as support elements and subordinated to an architectural configuration, as in the Stanza d'Eliodoro, differ in character and even prestige from an autonomous, freestanding image of Terminus. There was, in general, a wide range of hybrid, 'terminal' figures in sixteenth-century environments and imagery. ${ }^{43}$ The motif of a partly anthropomorphic, partly lithic figure includes a further type, with a separate and much richer tradition, especially in literary and historical sources well known in the Renaissance. In Athens, 'herms' stood guard throughout the city at a range of thresholds, apparently as apotropaic markers of boundaries both of civic and private space, sacred and profane. As simplified representations of Hermes, god of boundaries and crossroads, they consisted of the god's head atop a stone or timber post, with projecting genitals. Some were no doubt fairly primitive, but one-Hermes Propylaios ('before the gate') — stood on the approach to the Acropolis itself (Pausanias, Description of Greece 1.22.8). ${ }^{44}$ The importance of their herms to the Athenian population is fully established in the historical record, especially in Thucydides's account $(6.27-28)$ of the late fifth-century affair of the herms, involving the creation of alarm and chaos through the desecration or destruction of familiar boundary figures, an act that seemed to threaten the city's democratic order itself. ${ }^{45}$

The ubiquity of herms in Athens - it was, Thucydides insisted, a local phenomenon 46 - suggests a wide variation in quality of execution, which would presumably have been irrelevant to their symbolic, admonitory, and perhaps apotropaic function, and indeed there is evidence of the archaizing character of certain herms, some made of wood. Supposedly Kekrops, an early king of Athens, placed a wooden herm in the Temple of Athena. ${ }^{47}$ Herm figures of the Greek type (whether they were Roman copies is of no matter here) existed in early sixteenth-century Rome, as is clear from Maarten van Heemskerck's drawings of antiquities in Roman collections, ${ }^{48}$ as well as, occasionally, visual representations. A striking example of the latter is a stucco spandrel panel in Raphael's Loggia for Leo X, showing an Athenian-type herm next

\footnotetext{
43 Hersey, The Lost Meaning of Classical Architecture, 129. See now the various articles in S. Frommel, Construire avec le corps humain. Also Julien, 'Termes, atlantes, et caryatides'.

44 Platt, Facing the Gods, 35. The main source is Pausanias, Voyage around Greece, 1.22.8; 2.30.2.

45 Osborne, 'Erection and Mutilation'.

46 Osborne, 'Erection and Mutilation', 48.

47 Platt, Facing the Gods, 35-36; Quinn, 'Herms, Kouroi, and the Political Anatomy of Athens', 93 .

48 See $n .5^{2}$ below.
} 
to a young satyr or faun, ${ }^{49}$ suggesting that both iconographical types belong among grotteschi, in a context of the Bacchic subversion of artistic norms and even, as Horace complains, natural laws.

In sixteenth-century practice, the two types were generally not distinguished, perhaps because of their primarily decorative function and suitability for informal physical environments, like gardens as well as loggias, often in conjunction with grotesque ornament. ${ }^{50}$ Even in ancient Athens, herms served as ornaments of recreational spaces, like palaistra, ${ }^{51}$ and they were used in this way also in prominent gardens in Renaissance Rome, often carrying the likeness of important cultural figures, for example Socrates. ${ }^{22}$ Strictly, then, there is a sharp contrast between the associations of Greek herms with urban as well as urbane spaces and the Roman emphasis on rural, relatively primitive boundary stones. However, in the general enthusiasm for hybrid figures, not least within grotesque imagery, and for sculpture gardens full of marvels, ${ }^{53}$ such distinctions hardly mattered.

\section{5}

\section{Satyrs in the City}

Published in 1556 as part of Le antichità de la città di Roma of Lucio Mauro, Ulisse Aldrovandi's guidebook to the ancient sculptures of Rome, the first of its kind, met the demand of cultivated visitors to Rome interested in gaining access to prized artworks, many held in private collections. ${ }^{54}$ An especially famous collection belonged to the Della Valle family and was housed in the family's extensive palace complex, centrally located on the major processional route through the city, the Papal Way. Certain statues, apparently of statesmen and military commanders, were conspicuously displayed on the palace façade. ${ }^{55}$ Other objects from the Della Valle collection were temporarily

49 Dacos, Loggia of Raphael, Plate 179.

$5^{\circ}$ Dietrich-England, Sockelzone, 150-159, 166.

$5^{1}$ Quinn, 'Herms, Kouroi, and the Political Anatomy of Athens', 92.

$5^{2}$ Bentz, Cardinal Cesi and his Garden, 125, 315. For an intact herm, probably in the garden, sketched by Heemskerck, see Bartsch and Seiler, Rom zeichnen, 91, plate 32. A herm of Socrates in the Capitoline Museum perhaps once adorned a philosophical garden retreat: https://commons.wikimedia.org/wiki/File:Bust_Socrates_Musei_Capitolini_MC1163.jpg.

53 MacDougall, 'Ars Hortularum'.

54 On the guidebook and the unusual circumstances of its creation, see now Bentz, 'Ulisse Aldrovandi, Antiquities, and the Roman Inquisition'.

55 Christian, 'Architecture and Antique Sculpture', 94; Echinger-Maurach, Studien zu Michelangelos Juliusgrabmal, 190-198. 
mounted on a triumphal arch set up in front of the palace in 1513 on the occasion of the coronation procession (possesso) of Pope Leo x. ${ }^{56}$ Most notably, the arch presented the humanist, art-loving pope with the view of a famed, largely intact pair of antique statues of satyrs (Fig. 5$),{ }^{57}$ now in the Capitoline Museum, images of which proliferated, as in the margin of the tapestry of the Calling of St. Peter commissioned by Leo from Raphael for the Sistine Chapel. ${ }^{58}$ Often identified as statues of the goat god Pan, the figures stand against a vertical strip of stone; on their heads they carry baskets filled with grapes, indicating an original location within an architectural context, with the baskets serving as, or at least suggesting, capitals. As figures of natural abundance and instinctual vigor yet serving as architectural ornament, the Pans may have accidentally marked the transition, in decorations for the possesso and other festivities, from the display of flowers and other natural products to artifice, even including objects, like garlands, modeled on such naturalia. ${ }^{59}$

Echoes of the Della Valle Pans, as I shall refer to them, enjoyed 'extraordinary fame in the sixteenth century' and must have contributed to the fashion, inspired by Vitruvius's caryatids, for setting human or humanoid forms in the place of columns. ${ }^{60}$ Consistent with their role as carriers of meaning, Vitruvius placed his support figures in porticoes, that is, in structures mediating between interior and exterior and facing into the public realm. In the sixteenth century, a favored location was at a major threshold or point of transition, e.g., a portal into a palace or garden, or indeed the temporary arch on which the Della Valle Pans were displayed in 1513, at or at least near the effective threshold of the built-up area of the contemporary city. Within the Della Valle palace, the usual location of the Pans was as ornaments of a portico (Fig. 6), at the edge of a courtyard. ${ }^{61}$ Here the Pans were perhaps positioned in relation to a drain cover in the form of a large, horned mask of Ocean on the courtyard floor, ${ }^{62}$ as if setting up a contrast of representations of 'nature' — as configuration and as force.

$5^{6} \quad$ Stinger, Renaissance Rome, 51 , provides an effective account.

57 According to Bober et al., Renaissance Artists and Antique Sculpture, 122, Maarten van Heemskerck's painting The Triumph of Silenus (c. 1536) presents a jocular image of the triumphal arch, which, of course, the artist had not seen. For his drawing of the statues in situ, see below. See Barolsky, Infinite Jest, 100.

$5^{8}$ Karafel, Raphael's Tapestries, 85, fig. 73; Castelletti, 'Figure di sostegno zooantopomorfe', 143 .

59 Helas, '... mit Blumen und duftenden Kräutern bedeckt', 87.

6o Haskell and Penny, Taste and the Antique, 301-302, Cat. 75 .

61 Johnson, 'Portal of Empire and Wealth', 441.

62 Christian, 'For the Delight of Friends, Citizens, and Strangers', 140. 
Explicitly hybrid constructs, like a caryatid or indeed the monstrous creature imagined by Horace in the Art of Poetry, challenged the classical ideal of integral unity; in short, they embodied a metonymic combination of architecture and body rather than expressing a metaphorical conception of architecture as body, exemplifying and even guaranteeing proportional relationships ultimately grounded in metaphysics. Imprisoned in their architectural labor, however, Vitruvian caryatids refer to defeat and shame; in Renaissance versions of the motif, in contrast, a note of defiance may well be struck, especially when support figures represent creatures of the wild wood and the instinctual aspect of humanity. ${ }^{63}$ Some may even have had apotropaic character, as in the case of support satyrs planned by Cellini for an important portal at the palace of Fontainebleau (Fig. 7), one wielding a club. ${ }^{64}$

Nevertheless, the triumphal arch of 1513 for Pope Leo $\mathrm{x}$ was clearly intended to celebrate the owners, the Della Valle, and elicit the admiration of the pope. Moreover, the incorporation, or effective imprisonment, of the Pans in the arch — recalling the Vitruvian passage — possibly evoked the subordination of the notoriously unruly Roman populace to papal authority, ${ }^{65}$ if not, more generally, the idea of the submission or repression of the potent instinctual forces within the soul, as theorized by Plato and many later thinkers. ${ }^{66}$ We can be sure, in any case, that this deployment of the Della Valle Pans as anthropomorphic support figures accorded with their presumed function in Antiquity. As we saw, there are countless examples in sixteenth-century visual culture of combinations of architectonic and anatomical elements, but the Pans embody a more emphatic type of hybridity, which is part of their essence as mythological beings comprising both human and animal features, and so eliding the boundary between human and animal rather than that between nature and artifice, as in the case of caryatids. Further, though a being composed of both flesh and stone could certainly be imagined, it could not be supposed to exist as a life form. However, beings whose hybridity was inherent-satyrs, centaurs, and the like-were at least on the margins of possible existence, along with the 'wild men' of vernacular belief and imagery. They were, for example, accepted and published as existent by no less an authority than the Bolognese polymath Ulisse Aldrovandi in a volume, titled Monstrorum historia (1642, but written before his death in 1605), of his encyclopedic work on natural history (Fig. 8);

63 Castelletti, 'Figure di sostegno zooantopomorfe', 149.

64 Castelletti, 'Figure di sostegno zooantopomorfe', 148-149.

65 This is the view of Christian, 'Architecture and Antique Sculpture', 94.

66 The theoretical identification of an instinctual dimension of the soul begins with Plato, Republic $435 \mathrm{e}-436 \mathrm{a}$. 
remarkably, the satyr in Aldrovandi's book blows a trumpet, as if taking part in a celebration like that of ${ }^{1513} \cdot{ }^{67} \mathrm{In}$ his survey of Roman sculpture collections of 1557, moreover, Aldrovandi had noted the Della Valle satyrs, as he referred to them, perhaps deliberately using a more generic name than 'Pan'. ${ }^{68}$

In contrast to the Vitruvian connotations of caryatids, the Della Valle Pans brought to Rome a whiff of the wilderness - perhaps the mountains of Arcadia, the haunt of Pan and of Ovid's wolfman, Lycaon, who undergoes the first metamorphosis in the Metamorphoses (1.216-239). The Pans' Bacchic attributesbaskets of grapes and panther skins - evoke the capacity of the goat god, especially when allied with Bacchus and the effects of wine, ${ }^{69}$ to inspire irrational action even in those, like doomed Pentheus (Metamorphoses 3.511-733), confident in their control of self and others. ${ }^{70}$ There is an obvious connection between Dionysian (or indeed Pan's) subversions of established order and the formal inventiveness of grotteschi; thus, Raphael's Vatican Loggia provides a point of reference in terms of the 'sensation of abundance and celebration' that it radiates, 'sometimes with a certain Dionysian ardor.' ${ }^{71}$ These considerations perhaps place the distinctly Dionysian Della Valle Pans in a new light, for whether viewed in their more permanent position in the palace itself or as ornaments of the arch prepared for Leo x's admiration, they surely elided any stable categorization or assignment of meaning, especially that ascribed to caryatids by Vitruvius.

Torso and Pedestal: A Case of Strategic Bricolage

The repertory of classical art included various devices to set off an object from its environment and to ennoble it. At times, all that is needed is a pedestal, which raises an object above the ground but may also rely on sculptural or

67 Findlen, Possessing Nature, 25-26; Hansen, Art of Transformation, 77-78; Enenkel, 'The Species and Beyond', 112-116. For an image of the satyr, see MacRae, Monsters \& Madness (Online n.p.).

68 Aldrovandi, Tutte le statue antiche, 216. See Daly-Davis, Introduction, ibidem, 4-13.

69 For the association of Pan and Dionysos, see Homeric Hymn to Pan 7.36; Pausanias, Periegesis 2.24.7.

70 Pentheus, the king of Thebes who refused to acknowledge the divinity of Bacchus with fatal results, appears in Peruzzi's mythological frieze (c. 1518) in the Sala of the Farnesina. Aby Warburg included this in a panel of his Picture Atlas to 'stress how classical images of violence and woe recursively trouble the Renaissance imagination'; Johnson, Memory, Metaphor, and Aby Warburg's Atlas of Images, 90. Dacos, Loggia of Raphael, 106. 
decorative elements to elucidate or enrich the more prestigious object that it carries. ${ }^{72}$ In some case, a pedestal may be integrated within a sculptural object, as in the case of the herms or terms that consist of a head or head and torso above a more or less abstract shaft, often carved - at least in appearancefrom the same block of stone and, in some cases, providing a convenient field for an inscription. In contrast, the Romans produced pedestals as elaborate sculptural objects that could exist independently or be combined with a sculpture especially deserving of prestigious display. Such a pedestal existed in the Della Valle statue garden, where it was not prized for its inherent value but, rather, combined with a fragment of statuary, as we will see, to produce a new configuration.

During his sojourn in Rome from about 1532 to 1536 , the Dutch artist Maarten van Heemskerck made a celebrated series of drawings of sites-including sculpture gardens - and antiquities, apparently with the objective of producing a reasonably complete record of things to see in the city, which was still recovering from the damage and destruction inflicted during the Sack of 1527 . Indeed, the modern city was in its way as much a field of ruins as the ancient capital. ${ }^{73}$ For the most part accurately, Heemskerck's drawings document a number of major collections of antiquities in Rome, many located in courtyards or gardens; among them two spaces in the Della Valle palace complex. Though the palace complex itself remained a secure enclave during the Sack, the work on an extension, including an unusually elaborate sculpture garden, was perhaps itself a monumental gesture of cultural as well as physical recovery. In a view of the twin Pans (Fig. 5), Heemskerck shows them framing the central arch of a three-bay portico in a largely empty courtyard, evidently in the older palace, in which the most striking object is an enormous, apparently antique drain cover.

A further drawing, as well as a well-known print issued in 1553 by Hieronymus Cock based on it (Fig. 6), shows a very different display space in the newer section of the Della Valle complex. There is an immediate contrast with many of the sculpture collections recorded by Heemskerck, which he shows as chaotic jumbles of pieces of different type and degree of completeness. ${ }^{74}$ Rather, as both Heemskerck's image and a colored drawing by Francisco de Olanda make clear, this newer display was a carefully curated ensemble of antique statues, architectural fragments, plants, and modern stucco pieces; inserted into the

\footnotetext{
72 Weil-Garris Posner, 'On Pedestals'; Wright, '... con un inbasamento et ornamento alto'.

73 See the chapter 'Drawing Ruins in Post-Sack Rome', in DiFuria, Maarten Van Heemskerck's Rome, 81-108.

74 The point is made by Di Furia, Maarten Van Heemskerck's Rome, 403-404.
} 
walls, near the top, a series of stucco masks, evidently made specifically for the site, surrounds the garden. The whole installation was clearly designed for maximum effect on visitors; indeed, the courtyard contained extensive inscriptions of welcome touting the benefits of a visit for artists and poets. ${ }^{75}$

Located on the upper level of the new building that expanded the Della Valle compound to the north, the courtyard constituted a kind of hanging garden apparently designed, in accordance with a contemporary tendency, ${ }^{76}$ to be appreciated as a whole, however important some of the items within it. The patron was Cardinal Andrea Della Valle, who died in $1534,{ }^{77}$ probably around the time that Heemskerck made his drawing; the designer of the courtyard was Lorenzetto Lotto, a sculptor and decorator as much as an architect who had worked for Raphael, whose tomb he carved, perhaps as a collaborator on the Vatican Loggia. ${ }^{78}$ Lorenzetto's synthesizing ability, as well as his skill as restorer, was very much on display in the Della Valle hanging garden, which evoked an almost miraculously reintegrated Antiquity. ${ }^{79}$

As recorded by Heemskerck and in the Cock print, the hanging garden contains, in a very prominent position, an elaborate ancient three-sided pedestal on which is placed a legless and armless torso and head. It stands to the left of a loggia-like space in the foreground of the drawing, which otherwise shelters larger and relatively complete statues of more obvious impressiveness. Arnold Nesselrath has identified the three-sided base in an extant object, a support for a candelabra, that is now in the Louvre; he shows that it passed from the Della Valle collection to the Villa Borghese, where it is documented before its removal to Paris. ${ }^{80}$ Its obviously earlier disappearance from the Della Valle collection perhaps explains its absence from a drawing of the courtyard, attributed to Hendrick van Cleve (c. 1550), from the same viewpoint as Heemskerck's view, though everything else seems to correspond to the latter, as if based on it. ${ }^{81}$

For the eight inscriptions in the courtyard, see Christian, 'For the Delight of Friends', 145.

76 Christian, 'Architecture and Antique Sculpture in Early Modern Rome', 9; Karmon, The Ruin of the Eternal City, 161.

77 On the physical courtyard and its extant elements, see Christian, 'The Della Valle Sculpture Court Rediscovered', 847-850; DiFuria, Maarten Van Heemskerck's Rome, 403-406.

78 Williams, Raphael and the Redefinition of Art in Renaissance Italy, 184.

79 Dacos, Loggia of Raphael, $5^{8 .}$

8o Nesselrath, 'Drei Zeichnungen', 253, indicates that the base does not appear in the inventories for the Della Valle collection, explaining this by its transfer to the Borghese collection (most of the collection went to the Medici). But the disappearance of the base and its attached fragment from the drawing attributed to Hendrick van Cleve (c. 1550) suggests that the object was either moved within the Della Valle complex or already sold to another collector long before the formation of the Borghese collection.

81 Hendrick van Cleve, pen and ink drawing, Paris, BNF, Estampes, Rés. B 12; for a photo, 
In his discussion of the candelabra base, Nesselrath does not mention the statue fragment atop it, presumably because the original object has not come to light. If it still exists, the truncated statue resting on the base would not be difficult to identify. As represented in the Heemskerck drawing and the Cock print, the head, with its markedly tousled hair, is thrown back as if in ecstasy, giving the impression of a faun from a Bacchic progress. The specific hybridity of this apparent faun-on-a-base arises from a surely deliberate montage of disparate elements from different sources. As Nesselrath points out, the base in Paris carries a relief of a naked satyr carrying a wine jar, suggesting a Bacchic quality that apparently extended to the compound object as a whole, thus linking it to the figures of Pan, the most famous statues in the collection, with their expressly Dionysian attributes, notably the baskets on their heads containing grapes.

\section{Erasmus in Rome: The Terminus Motif}

The prominent position of the composite object in the Della Valle hanging garden may perhaps be justified through its artistic quality and the interest of its imagery. However, the motif of a base carrying a head or upper body of a man with tousled hair was - or became - widespread as an image of the god Terminus, patron of boundaries. The simple, often quadrangular base alluded to the origin of the motif in the stones or posts set up in rural districts to mark the limits of a field or a property; Ovid, for example, emphasized the archaic character of this custom in his Fasti (2.639-662) when he described an apparently annual ceremony in which adjoining property owners, evidently peasant farmers, and their families would meet to honor the god of boundaries and confirm the existing spatial organization. On this occasion the boundary stone would become a kind of altar as the focus of sacrifices as well as, presumably, some kind of shared feast.

In Roman religion, the cult of the god Terminus was one of the most ancient. Livy (Ab Urbe Condita 1.55) and other authors relate an important incident, when Rome was still under regal rule, connecting rural practice to the heart of the city. ${ }^{82}$ In response to an augury, King Tarquin sought to replace earlier

see http://expositions.bnfffr/renais/grand/o23.htm. The drawing was discovered by Nesselrath, 'Drei Zeichnungen von Marten van Heemskerck', 253. See also Christian, 'For the Delight of Friends', 134-135, fig. 2.

82 An important Renaissance source was Lilius Gregorius Giraldus, Aenigmata (Basel, 1539), a volume owned by Erasmus, whose copy contains his drawing of Terminus; Rowlands, 'Terminus', 52 . 
shrines on the Capitoline Hill with a temple dedicated to Jupiter, King of the Gods, but Terminus, who was already in possession of the hill, refused to give ground to the Olympian interloper. In the end he was able to keep his place, now enclosed within the massive new temple of Jupiter Optimus Maximus, though his shrine was open to the sky, presumably through an opening in the temple's roof. In this way, a god associated with boundary stones or posts set into the ground received a cosmic dimension at the heart of the Roman state, while Jupiter became the ultimate guarantor of spatial divisions. ${ }^{83}$ The implication is that the institution of boundary stones was even older, and in fact was attributed by Plutarch (Life of Numa 16) to King Numa, legendary founder of archaic Roman cult practices in general. Unsurprisingly, ancient boundary stones seemed to belong to the natural world; hence as Augustine noted (City of God 21.4), when a stone was set up, charcoal (carbones) was placed beneath it to indicate its appointed function as a spatial marker, or it might be taken asand otherwise seemed to be-a naturally occurring boulder. ${ }^{84}$ Presumably the burned wood was the result of a sacrificial ritual, not unlike the ritual of founding a city, even Rome itself, when sacrificial material was placed in a small pit. ${ }^{85}$

The defiant retort of Terminus to Tarquin's demands was 'Cedo nulli' (I yield to no one). Around 1509 this was adopted as his motto by the Dutch humanist Erasmus when he was traveling in Italy in the company of a young Scottish pupil, Alexander Stuart, a member of the former royal house, who presented his teacher with a ring carrying an antique carved gem of a mature, bearded man's head above an abstract block or post (Fig. 9, left). ${ }^{86}$ No doubt assimilating the block to a boundary stone, Erasmus interpreted the image as that of Terminus, rather than of Dionysus, as the bearded figure is now identified. ${ }^{87}$ In subsequent images of Terminus associated with Erasmus, e.g., his seal punch (now in Basel), the head is that of a distinctly younger man with tousled hair (Fig. 9, right). Such a visage also appears in a painting of Erasmus's Terminus attributed to Holbein (Fig. 10), as well as in other designs by the latter. ${ }^{88}$ In his voluminous

83 Platner and Ashby, Topographical Dictionary of Ancient Rome, ad voc., Terminus.

84 St. Augustine, City of God 21.4. Online: https://ccel.org/ccel/schaff/npnfioz.iv.XXI.4.html.

85 On the institution of the mundus, see Rykwert, The Idea of a Town, 58-59.

86 Rowlands, 'Terminus', 50; Schmitt, 'Der Siegelring des Erasmus von Rotterdam, n.p., Online.

87 For representations of Dionysus as a mature bearded man, see van Loyen and Regn, 'Dionysus', 240, and on the god's emergence as a cultural hero and peaceful ruler, 243. Erasmus may well have known of the relevant passage in Diodorus Siculus, Bibliotheca (Latin translation 1449). If so, his misidentification of the figure on the ring was perhaps intentional.

88 Rowlands, 'Terminus', 53. 
correspondence, in short, Erasmus sealed letters with an image of Terminus entirely dissimilar from that on the ring given him by this pupil, and a similar image of a younger man, clean-shaven with short, tousled hair, appears in related images associated with the humanist. This abandonment of the ancient model, as portrayed both on the image and the ring, demands explanation, especially as a mature Terminus would have been appropriate in view of the antiquity of the Roman god. Perhaps, in a generalized way, the new, youthful image evoked the unfortunate Alexander Stuart, whose death-his premature terminus - on Flodden Field in 1520 Erasmus lamented. ${ }^{89}$ It is perhaps also relevant that deified Youth (Iuventas) was worshipped alongside Terminus on the Capitol, having also resisted Tarquin. ${ }^{90}$ Finally, as we will see, Erasmus may have had in mind a composite statue in Rome that uncannily resembled the images of Terminus associated with the humanist until the end of his life.

In correspondence with potential patrons as well as fellow scholars, Erasmus put his signet ring to good use. Though famously a man of the text, in what amounted to a long-term campaign of self-promotion, Erasmus relied on images of himself to foster what might be called his celebrity stature in Europe. ${ }^{91} \mathrm{~A}$ major collaborator was the leading Flemish artist Quentin Massys or Metsys (1466-1530), based in Antwerp, who in 1517 made a portrait of Erasmus, to whom he was apparently close. ${ }^{92}$ Two years later Massys made a medal with the likeness of Erasmus on the obverse and Terminus on the reverse (Fig. 11); it was a convenient and compact vehicle for sustaining the humanist's network of support and conveying, through text and image, crucial aspects of his character, as he saw it. ${ }^{93}$ Thanks to Erasmus's fame, the Terminus motif of a head on a block would achieve currency in sixteenth-century visual culture, as noted below.

Massys's medal leaves no doubt about the identity of the figure on the reverse: within a rocky landscape, the name Terminus appears on a roughly quadratic block, opposing order to rugged surroundings. Erasmus's slightly

89 Rowlands, 'Terminus', 5o; Schmitt, 'Der Siegelring des Erasmus', 5.

9o Platner and Ashby, Topographical Dictionary, as cited above; Woodard, 'The Disruption of Time in Myth and Epic', 86. Echinger-Maurach, Studien zu Michelangelos Juliusgrabmal, 208-209, suggests that Erasmus simply did not concern himself with the figural part of the emblem. This seems unlikely in the light of later developments. Rowlands, 'Terminus', 53, suggests that Terminus and Juventas are somehow merged in the image, though the Roman goddess of Youth is always female, as is emphasized by Horace, Odes 1.30.7. See Rubinstein, 'Youth and Spring in Botticelli's Primavera', 249-25o.

91 For the term 'moral portrait', see, e.g., Russell, 'Wives and Widows', 144.

92 Rowlands, 'Terminus', 5 o.

93 Sher, Currency of Fame, 349-350, Cat. No. 157. 
altered motto Concedo Nulli is inscribed to either side of the bust of the god, which rests on the block. Terminus himself appears relatively youthful and clean-shaven, but also somewhat disorderly, with naked shoulders and strikingly unruly long hair. There is at least a generic resemblance to the head of Erasmus on the other side of the medal, though the humanist's longish hair is pushed back over and partly in front of his ears, and confined within a large cap. Clearly the medal maintains the young, beardless type of Terminus of the humanist's signet ring; in contrast, depictions of Terminus as an older man with a full beard, like the figure on the ancient gem given to Erasmus in 1509, occurred in other contexts, notably an emblem in the expanded 1546 edition of Andrea Alciato's Emblemata (Fig. 12). ${ }^{94}$ Here, of course, there is no explicit association with Erasmus, though presumably most readers of that extraordinarily successful book would have made the connection.

The Latin word concedo (a variant of cedo, apparently without difference of meaning) on the reverse of Massys's medal is inscribed on its bronze surface. The placement of the inscription in front of and in line with Terminus's mouth, however, invites the viewer to perceive the inscription as if uttered by the god, somewhat in the fashion of a modern speech bubble. Taking Jean Guillaume's phrase literally, indeed, this is a 'devise parlante', that is, words uttered by Erasmus, as if asserting his intellectual independence, if not superiority. ${ }^{95}$ This does not, however, accord with the Latin inscription curving around the periphery of the medal, Mors ultima linea rerum (death, the ultimate boundary of all things), quoted from Horace's Epistles (1.16.79). The motto makes clear that the message was not Erasmus's own obduracy but, rather, recognition of the power of death, the ultimate boundary. In spite of this disclaimer, the medal was controversial, and Erasmus was charged with arrogance for seeming to place himself above the great scholars of his own day, or of Antiquity. ${ }^{96}$

Erasmus's visit to Rome occurred long before Heemskerck's sojourn in the city, c. 1532-1536, but at a time when collections of antiquities were attracting connoisseurs and the curious. There is no evidence that Erasmus or Massys saw the 'Terminus' in the Della Valle palace, or a representation of it, but the likeness to the figure on the former's device is at least suggestive. As we saw,

94 See the concordance posted by L. Barker, M. Feltham, and J. Guthrie, Department of English, Memorial University of Newfoundland: http://www.mun.ca/alciato/c158.html. The image in Emblem No. 158 in the second edition of the Emblemata of 1546 shows the god's upper body on a square but not cubic block (less high than wide); on the block is inscribed Erasmus's motto. The block is partly sunk into the earth.

95 Guillaume, 'Hic Terminus Haeret', 188.

96 Guillaume, 'Hic Terminus Haeret', 188. 
Heemskerck's views of the Della Valle property belonged to a larger project involving careful study of sites and motifs, apparently with a view to incorporating them in later paintings or even providing work for print-makers. But the Dutch presence in Rome certainly did not begin in the 1530s; after all, there had recently been a Dutch pope, Adrian vi (1522-1523), and even if Adrian had limited interest in antiquities, there were many Dutch artists and scholars, besides Erasmus, who did. The artists included Heemskerck's master, Jan van Scorel, who was in Italy from 1518 until 1524 and was appointed curator of antiquities at the Vatican by Pope Adrian. Before coming to Rome, Heemskerck worked in Haarlem with van Scorel, who gave him letters of introduction to Cardinal William of Enckenvoirt, a long-term resident of Rome who probably housed the artist as he sought to establish himself there. ${ }^{97}$ Quentin Massys never traveled to Italy, but when making the already-mentioned grand medal of classical inspiration for Erasmus in 1519 (a unicum in his oeuvre), he worked closely with the humanist (Fig. 11). ${ }^{98}$

Terminus and Marsyas: Bodies in Parts

For reasons already noted, Erasmus's emblem was familiar in the 1530 s in various media and forms, and Heemskerck would certainly have known of it. The most striking aspect of the imago of the emblem was the combination of human and lithic elements, as in the Della Valle 'Terminus'. Moreover, the Bacchic iconography resonated with Bacchic figures and imagery as in the Della Valle Pans or even Michelangelo's statue of the god himself, which Heemskerck drew as a damaged Roman antiquity in the chaotic setting of Jacopo Galli's sculpture garden (Fig. 13) ${ }^{99}$ In sharp contrast with the Della Valle garden, this 'ramshackle display' 100 provides an appropriate setting for the tipsy god, with his unsteady posture and eyes determinedly fixed on the wine cup in his hand, as if in a parody of the antiquarian's gaze. ${ }^{101}$

In his drawing of the Della Valle sculpture garden, Heemskerck showed the 'Terminus' adjacent to a life-size statue of an Olympian god, perhaps Jupiter.

\footnotetext{
97 DiFuria, Maarten Van Heemskerck's Rome, 39-56, 87.

98 It was made 'ad vivam'. Silver, The Paintings of Quinten Massys, 111, notes 'Erasmus's careful supervision of his personal emblem for the medal'.

99 Barkan, Unearthing the Past, 203, notes that the statue's hand is broken off, as if to increase the all'antica effect.

100 DiFuria, Maarten Van Heemskerck's Rome, 406.

101 Freedman, 'Michelangelo's Reflections on Bacchus', 121-135.
} 
A more appropriate pairing is that with a well preserved, or at least restored, statue of the satyr Marsyas (now in the Uffizi) ${ }^{102}$ against the opposite wall, in a position of prominence indicative of the cardinal's view of the statue's aesthetic and cultural value (it was perhaps the model for the representation of Marsyas by Raphael in the Stanza della Segnatura). ${ }^{103}$ Ovid's story of Marsyas's hubristic contest with Apollo and subsequent death by flaying (Metamorphoses $6.382-400$ ) is set in a pastoral landscape in which Marsyas belongs both as a satyr and as an exponent of the shepherd's crude instrument, the panpipes, with which he fatally challenges Apollo, god of the refined lyre. The setting, moreover, is identified not only as pastoral but also as Phrygian, i.e., 'Asian', associating it with a territory regarded in Antiquity as the place of origin of Dionysus. ${ }^{104}$ In such a landscape, then, Marsyas belongs in a Dionysian context, and, indeed, ancient sources confuse him with Silenus. ${ }^{105}$ In contrast to the fixity of Terminus, moreover, the exposed nerves and muscle of Ovid's Marsyas and the satyr's own tears and blood dissolve into a river (the 'most liquid of Phrygia') swollen by the tears of the mountain nymphs, shepherds, and satyrs who weep for him.

For the ancient Romans, Marsyas held further, somewhat surprising associations. The existence of a statue of Marsyas in the ancient forum is well documented; it was used as a meeting-place both by lawyers and prostitutes (Seneca, On Benefits 6.32). ${ }^{106}$ More celebrated was its positive association with liberty; indeed, in his commentary to the Aeneid (4.528), Servius wrote of Marsyas as an emblem or sign of the freedom of the state (indicium libertatis). Further, he identified him as a minister of Bacchus as god of liberty and as patron, under the name Liber pater, usually given to Bacchus, of the spring festival of the Liberalia. ${ }^{107}$ This included a ribald annual procession emphasizing the god's

102 It is a statue of the 'white' type, e.g., before the removal of the skin; Bober and Rubinstein, Renaissance Artists and Antique Sculpture, 82-83, No. 32. On the interest of artists in figures of Marsyas in the later Renaissance, see Jacobs, '(Dis)Assembling', 426-448.

103 This is suggested by Freedman, Classical Myths in Italian Renaissance Painting, 120.

104 Otto, Dionysus: Myth and Cult, 52. An unresolved aspect of the ancient view of Dionysus was that he was both an eastern interloper (from Phrygia or sometimes other Asian territories) and also part of Greek cult from the earliest times.

105 Pausanias, Description of Greece 2.7.9.

106 Platner and Ashby, Topographical Dictionary of Ancient Rome, ad voc. Statua Marsyae.

107 Augustine, City of God 7.21: 'Among other rites which I am compelled from the greatness of their number to omit, Varro says that in Italy, at the places where roads crossed each other the rites of Liber were celebrated with such unrestrained turpitude, that the private parts of a man were worshipped in his honor. Nor was this abomination transacted in secret that some regard at least might be paid to modesty, but was openly and wantonly displayed. For during the festival of Liber this obscene member, placed on a car, was carried with great 
association with fertility; as St. Augustine (City of God 7.21) noted with revulsion, a giant phallus was carried in a wagon around crossroads and eventually into the city. ${ }^{108}$ And in his account of the Liberalia in the Fasti (3.789-79o), Ovid addressed Liber as endowed with horns, as if assimilating him to Pan or his Roman counterpart, Faunus. ${ }^{109}$ Emphasizing his archaic aspect, Ovid (Fasti 3.727-734) claimed that Liber introduced burnt sacrifice to Rome: altars were previously 'without honor'. The question arises of a connection between Bacchus/Liber and Terminus, especially given the specific inclusion in the Liberalia procession of crossroads, where boundary markers and signposts typically stood.

\section{$9 \quad$ Erasmus and Horace}

Erasmus responded to charges of perceived arrogance in his choice of motto, (Con)Cedo nulli, with a strategic reframing that justified his retention of his motto. ${ }^{110}$ In the medal that Quentin Massys made for him in 1519, the Latin inscription curving around the edge-Mors ultima linea rerum (death, the ultimate boundary of all things) — suggests that it was not the humanist who pronounced the defiant claim, Cedo nulli, but Death, thereby shifting the meaning of the motto in a direction compatible with Christian sentiment. The line itself, however, came from a distinctly pagan work, one of Horace's verse epistles (1.16.79). It is indicative of attitudes, or at least a sensibility, that Erasmus shared with the ancient author, whose conception of the relationship of art and nature was fundamental to the aesthetic and even moral discourse of humanism. In a range of texts, Horace wrote about literal boundaries (in Latin termini or limites) in the landscape, as well as about various metaphorical boundaries, notably those between natural and artificial phenomena or between different orders of being.

honor, first over the crossroads in the country, and then into the city' (the emphasis on crossroads suggests that the cult of Mercury or even Terminus was also involved). On the ritual, see J.F. Miller, 'Ovid's Liberalia', 199-224. Miller documents the political overtones of both Liber and Marsyas, especially in plebeian circles, and notes that for the most part Ovid uses the names Liber and Bacchus interchangeably.

108 J.F. Miller, 'Ovid's Liberalia', 202, associates this with popular Bacchic festivities described by Vergil, Georgics $2.385-396$.

109 J.F. Miller, 'Ovid's Liberalia', 199-224.

110 Guillaume, 'Hic Terminus Haeret', 188. 
From a young age, Erasmus often expressed his enthusiasm for Horace, whom he explicitly preferred to Virgil or Ovid. ${ }^{111} \mathrm{He}$ would certainly have known the Art of Poetry, which was not only a fundamental text in Renaissance discussions of poetics or aesthetic theory ${ }^{112}$ but which also explicitly addressed the concept of limit or boundary in and beyond literary discourse. At the outset, as we saw, Horace insisted that artistic license must remain within limits and that, beyond the limits, monstrosity lies. Such limits are ultimately set by nature, which expressly does not permit hybridity across distinct species, like tigers and serpents. Horace's famous tag ut pictura poesis points to the representational expectation of mimetic art; an artist must represent what exists in nature, that is, in the world as experienced. In the early sixteenth century, Horace's treatise assumed canonical status, though not to the point of affecting the fashion for grotesque imagery, which embraced exactly the kinds of hybridity that Horace inveighed against. ${ }^{113}$ A similar fate befell Vitruvius's attack on representations in what is now known as Third Style wall painting of impossible structures and unnatural mixing of generically distinct elements. In short, Renaissance grotesques were 'classical in origin, but anti-classical in substance.'114 There are also obvious literary echoes, notably in Ovid's Metamorphoses, in which no substance is immune from the possibility of transformation, and in particular stones can become humans, and humans stones. ${ }^{115}$

\section{Horace, Boundaries, and the Rebellion of Nature}

Though at the outset of the Ars poetica Horace insisted on a criterion of naturalness in textual as well as visual composition, the term 'nature' itself does not appear until well into the text, in connection with the human capacity to

111 Vredeveld, introduction to Desiderius Erasmus, Poems, xxx-xxxi; Lowry, The World of Aldus Manutius, 228.

112 Golden, 'Reception of Horace's Ars Poetica', 392-393. Shortly after his great Dante edition and commentary appeared, Cristoforo Landino published in 1482 an edition of Horace's Opera with a verse preface in Horatian style by Poliziano; Moss, 'Horace in the Sixteenth Century', 66-67; Kennedy, 'Humanist Classifications of Poetry', 92; Friis-Jensen, 'Commentaries on Horace's Art of Poetry', 228-239.

113 On the question of reception, see Laird, 'The Ars Poetica', 132-143. Commenting on the image of the poet as a raging bear at the end of the poem (138), and then as a bloodsucking leech, Laird notes the irony of Horace's denunciation of hybrid beings, given the discordances within the Art of Poetry itself.

114 Zamperini, Ornament and the Grotesque, 122.

115 On the Ovidian aspect of Renaissance grotesques (i.e., emphasizing a literary rather than the usual visual model of the Domus Aurea), see Kommerell, Metamorphosed Margins. 
feel and express strong emotions. ${ }^{116}$ Horace had already noted $\left(65^{-67}\right)$ that language itself is subject to natural processes of change and decay, as are human interventions in landscape, e.g., a lake drained and converted into a rich agricultural resource for neighboring cities, but fated to revert ultimately to swamp. ${ }^{117}$ Accordingly, humans must accept limits, especially the final limit, which is death, a conviction that Erasmus found congenial. Horace extended the argument from a consideration of limits in time to limits in space, in other words covering the semantic range of terminus from temporal end to spatial boundary. Striking passages elsewhere in Horace's oeuvre reinforce the point, as well as the central importance of the notion of terminus, across its semantic range, in his thinking.

The emphasis on the inevitability of death accords with Horace's praise of modest living, 'in accordance with nature' (Epistle 1.10.12: Viuere naturae si conuenienter oportet ...). ${ }^{118}$ Horace's own modest living at his famous, evidently well-appointed farm in the Sabine Hills nevertheless contrasted with the more luxurious digs of others. ${ }^{119}$ Indeed, he claimed that he could have made his farm more luxurious but chose not to do so, emphasizing his status as a caretaker, destined to leave his property to others. Accordingly he attacked property owners who behave as if they are immortal; they invest in conspicuous and expensive architecture, as if able to suppress nature by exceeding temporal limits, most obviously, but also in terms of immoderate self-promotion through architecture and immoderate, but futile environmental interventions. Horace summed up his position in a famous line: 'you can throw out nature with a pitchfork, but she will always find her way back in.' Horace reserved particular $\operatorname{scorn}(2.18)$ for the owners of coastal property who expand the footprint of their villas beyond the natural shore onto landfill; 'Already on the edge of the grave, you contract for cut marble. You forget your tomb and build a palace, pushing hard to extend the shore ..., as if there was not enough coastline already!' Here the critique of luxury merges with the theme of futile battle with the sea, a familiar topos in ancient literature. ${ }^{120}$ As Horace insisted in another poem

\footnotetext{
116 Ferriss-Hill, Horace's Ars Poetica, $5^{2}$.

117 Ferriss-Hill, Horace's Ars Poetica, 66-67.

118 I give the most likely translation, but the phrase vivere naturae can mean 'live for nature', at least until the reader reaches the end of the line!

119 Fitch, 'Nature in Horace', 28-29; Thomas, 'The Landscapes of Horace', 8-34.

120 Most famously in Herodotus's account of Xerxes's conflict with the sea; Wendt, 'Xerxes am Tay', 61-9o. As for Horace, in Odes 1.2, 'the sea represents an awesome force with which humans must contend'; on this and similar passages, see Porter, Horace's Poetic Journey, 66 .
} 
(Odes 1.3), moreover, to entrust oneself to the sea is the height of audacia, that is, 'the rashness or recklessness with which humans break the limits built into the cosmos.'121

Horace then turned to the rich man's agricultural holdings: 'But why do you greedily tear down the boundary stones that edge the fields, and leap over the property limits of your tenants [clientes: perhaps 'those dependent on you']?'122 This concerns the destruction not of a natural but of a traditional cultivated landscape, as noted above, though overseen and ideally protected by Horace's favorite god, and perhaps alter ego, Faunus. ${ }^{123}$ Horace's account of change in the land emphasizes the desperate plight of peasants driven from their homes and taking the road, clutching their household gods as well as their unwashed children. Heightening the effect is an unmistakable echo of the tragic fate of dispossessed peasants in Vergil's Eclogues. ${ }^{124}$ Horace, in contrast, was 'contented enough, blessed with my one and only Sabine Farm'; the implication is that he respected the boundaries existing on the land, as well as the moral limits that here coincide, as well as elsewhere in Horace, with physical ones. ${ }^{125}$

In several passages, Horace indicated or implied that he regards the traditional landscape of frugality and responsible husbandry to be as 'natural' as the woods or watercourses. ${ }^{126}$ John Fitch emphasizes the poet's admonition to brothers who have inherited a farm (Satires 2.3.177-178): 'Don't reduce or increase what your father considers enough, and what nature sets as a limit' (my italics). The traditional boundaries of a farm, then, represent a kind of modus, a spatial expression of a moral posture that runs through all Horace's works. From this perspective, boundary markers—termini-are a key element of a peasant world regarded as shaped at least as much by nature as by culture, or by both in harmony. For all the greed of impious landowners, however, Horace did not explicitly identify boundary stones as sacred, in spite of the cult of Terminus. In contrast Ovid, in his calendar poem Fasti (2.638-641), closely associated the personified Terminus, a god, and the humble boundary marker (indicium) set in the ground, hardly recognizable as artificial. He apostrophized Terminus, 'God of wood or stone, whiche' er you be, Marking the bounds, you claim divinity'.

\footnotetext{
121 Fitch, 'Horace, Odes 1.3', 32.

122 'Quid quod usque proximos/revellis agri terminos et ultra/ limites clientium/ salis avarus?'

123 Parker, 'Faunus in Ovid's Fasti', 200-201.

124 Nielsen, 'Virgil: Eclogue I', 154-160, discusses the poet's review of alternate responses to the land expropriations under Augustus.

125 Fitch, 'Horace, Odes 1.3', 35.

126 Fitch, 'Nature in Horace', 23-35.
} 
Appropriate to the standard meaning of terminus as 'end', in the Fasti (2.49$5^{\circ}$ ) the god's festival, the Terminalia, takes place in late February as the official end of the Roman ritual year, ${ }^{127}$ again spatial and temporal as well as cultural ends coincide. In his account of the Terminalia festival, as we saw, Ovid emphasized the simple ceremony through which peasants from adjoining farms meet at a boundary stone between their properties to perform a ritual that clearly built neighborhood solidarity while connecting everyday custom and practice to a kind of transcendent authority. Ovid mentioned the family members who take part in the ritual in a way that echoes Horace's account of the peasant family expelled from their farm, as noted above. No mere marker, the boundary stone is a kind of altar, hallowed by sacrifice and festivity.

The Erasmus Monument

Before Quentin Massys's death in 1530, Erasmus had found another artist to help him cultivate his image. A citizen of Basel, Hans Holbein (1497-1543) made portraits of Erasmus, from 1523, which were especially successful and propelled him to international fame and, in particular, the position of painter to the king at the court of Henry vin of England. ${ }^{128}$ When Erasmus of Rotterdam died in 1536, Holbein was back in Basel, where he accepted the commission to design a civic memorial to the humanist, a stained-glass window in the hall of the university (Fig. 14). By about 1540, a print of Holbein's design was in circulation among Erasmus's many admirers throughout Europe. Erasmus stands within an elaborate architectural surround; he rests his right hand affectionately on a figure of Terminus, truncated as usual and placed on a sculpted base. Terminus's armless upper body, muscular and naked, is shown facing forward, while the head looks away to Erasmus's right, the opposite direction from the latter's pose and glance; this injects an vivid element of contrapposto. There is also a striking contrast between the lively figure of Terminus and the aged and infirm humanist.

Such an image of Terminus accords with the youthful figure we have already seen on the humanist's seal and other images associated with him, especially the medal that Massys made for the humanist in 1519 (Fig. 11). In the Cleve-

127 Nevertheless, it is not the final festival included in the Fasti for February. For a rather complicated explanation, see Martelli, Ovid's Revisions, 140-141. For the similar associations, both temporal and physical, of Terminus and Janus (who begins the year), see Banta, 'The Gates of Janus', 267 .

128 Bätschmann and Griener, Hans Holbein, 157 . 
land painting (Fig. 10) and other images of Terminus, there is no sharp break between the body and the block. Similarly, in the print Terminus's naked torso is shown extending almost down to the groin, so that the incipient rise of his hips appears to either side of his lower belly, just above the relatively small base..$^{129}$ The name 'Terminus' is inscribed not on the base, as is usual, but on the belly, just above a ram's head approximately where Terminus's genitals would be if the body extended lower. There is some irony in the unmistakable Dionysian resonance, for the older bearded figure on Erasmus's ring stone, which he identified as Terminus, was in fact Dionysus, as he is often represented in Greek art, as noted above. In the images of Massys and Holbein, in contrast, cleanshaven, curly-haired, and youthful Terminus acquires a distinctly Bacchic overtone, somewhat like the 'Terminus' of the Della Valle collection, which Erasmus may well have seen during his sojourn in Rome in 1509, perhaps already on its pedestal, with its Bacchic imagery.130

In Holbein's print, the group of Erasmus and Terminus are contained within an elaborate portal framed by long-haired, bearded, male terms. Above the portal, relatively small ignudi hang ornament in the form of festoons and cornucopiae. A lion's head mask appears in what would be the keystone, if not for the pliant, strapwork-like material of which it is represented as composed. From this 'keystone' dangles a strapwork cartouche inscribed with Erasmus's initials; his motto, however, is not included in the print, perhaps because of the controversy that it had aroused. A larger cartouche appears underneath the arch; it is framed by hybrid, harpy-like female figures that contrast with the cherub's head at the summit of the arch but seem consonant with the ram's head and connect the print to the fashion for grotesque imagery, which, as we saw, often featured 'terms' and similar hybrids. Contrasting with the youthful Terminus, the aging terms function, like those of Julius's tomb, as tragic markers of the ultimate threshold, which Erasmus was about to traverse, from this life to the next. This boundary marker is entirely and ineluctably a part of the natural order, which no human can escape, a condition on which no poet wrote more movingly than Erasmus's favorite, Horace.

129 On the various images of Terminus made by Holbein, see Rowlands, 'Terminus', 50-54.

130 Christian, 'The Della Valle Sculpture Court Rediscovered', 847. 


\section{Bibliography}

Aldrovandi, Tutte le statue antiche, che in Roma in diversi luoghi, e case particolari si veggono ..., in: Mauro, L., Le antichità della città di Roma, Venice, Ziletti, 1556, 115-315.

Armstrong, Vergil's Green Thoughts: Plants, Humans, and the Divine, Oxford and New York, Oxford University Press, 2019.

Baader, Hannah et al. (eds.), Im Agon der Künste:paragonales Denken, ästhetische Praxis und die Diversität der Sinne, Munich, Fink, 2007.

Baker-Smith, D., 'Thomas More', in: Zalta, E.N. (ed.), The StanfordEncyclopedia of Philosophy, (Winter 2019), Online: https://plato.stanford.edu/archives/win2o19/entries/ thomas-more/.

Banta, J., 'The Gates of Janus: Bakhtin and Plutarch's Roman Meta-chronotope', in: Larmour, D., and D. Spencer (eds.), The Sites of Rome: Time, Space, Memory, Oxford and New York, Oxford University Press, 2007, 238-270.

Barkan, L., Unearthing the Past:Archaeology and Aesthetics in the Making of Renaissance Culture, New Haven and London, Yale University Press, 1999.

Barolsky, P., The Faun in the Garden, University Park, Penn State Press, 1994.

Barolsky, P., Infinite Jest: Wit and Humor in Italian Renaissance Art, Columbia, MO, University of Missouri Press, 1978.

Barolsky, P., Ovid and the Metamorphoses of Modern Art from Botticelli to Picasso, New Haven and London, Yale University Press, 2014.

Bartsch, T., and P. Seiler (eds.), Rom zeichnen: Maarten van Heemskerck 1532-1536/37, Mann, Berlin, 2012.

Bätschmann, O., and P. Griener, Hans Holbein, Cologne, DuMont, 1997.

Beard, M., J. North, and S. Price (eds.), Religions of Rome: Volume 2, Cambridge and New York, Cambridge University Press, 2018.

Beck, T.E., 'Gardens as a “Third Nature”: The Ancient Roots of a Renaissance Idea', Studies in the History of Gardens \& Designed Landscapes, 22:4 (2002), 327-334.

Bentz, K.M., Cardinal Cesi and his Garden: Antiquities, Landscape and Social Identity in Early Modern Rome, PhD diss., Penn State University, 2003.

Bentz, K.M., 'Ulisse Aldrovandi, Antiquities, and the Roman Inquisition', Sixteenth Century Journal 43:4 (2012), 963-988.

Bober, P.P., R.O. Rubinstein, and S. Woodford, Renaissance Artists and Antique Sculpture: A Handbook of Sources, London, Harvey Miller, 1987.

Burroughs, C., 'Raphael and the Paragone: From Parnassus to the Plague', Iconocrazia 17 (2020). Online: http://www.iconocrazia.it/raphael-and-the-paragone-from-parnass us-to-the-plague/.

Castelletti, C., 'Figure di sostegno zooantopomorfe. Pan, satiri, e satiresse in funzione tettonica o pseudo-tettonica nell'Antichità e nel Rinascimento', in: Frommel, S. (ed.), Construire avec le corps humain, 1:141-156. 
Christian, K.W., 'Architecture and Antique Sculpture in Early Modern Rome', in: Malgrave, H., and A.A. Payne (eds.), Companions to the History of Architecture: Volume I, Renaissance and Baroque Architecture, New York, Wiley, 2017, 73-103.

Christian, K.W., 'The Della Valle Sculpture Court Rediscovered', The Burlington Magazine 145:1209 (December 2003), 847-850.

Christian, K.W., 'For the Delight of Friends, Citizens, and Strangers: Maarten van Heemskerck's Drawings of Antiquities Collections in Rome', in: Bartsch, T., and P. Seiler (eds.), Rom zeichnen: Maarten van Heemskerck 1532-1536/37, Berlin, Mann, 2012, 129-156.

Christian, K.W., 'Raphael's Vitruvius and Marcantonio Raimondi's Caryatid Facade', in: Wouk, E.H. (ed.), Marcantonio Raimondi, Raphael, and the Image Multiplied, Manchester, UK, Manchester University Press, 2013, 66-83.

Corso, A., The Art of Praxiteles: The Development of Praxiteles'Workshop and Its Cultural Tradition Until the Sculptor's Acme (364-1 BCE), Rome, L'Erma di Bretschneider, 2004.

Dacos, N., The Loggia of Raphael: A Vatican Art Treasure, New York, Abbeville Press, 2008.

Daly-Davis, M., 'Introduction' to Ulisse Aldrovandi: Tutte le statue antiche ... Part I. Introduction and Full Text (AMs Historica, Collezione digitale di opere storiche, University of Bologna, 2009), 4-13. Online: http://archiv.ub.uni-heidelberg.de/artdok/704/ 1/Daly_Davis_Fontes29.pdf.

Dietrich-England, F., Die Sockelzone der Stanza di Eliodoro: ein Entwurf Raffaels, Weimar, VDG, 2006.

DiFuria, A.J., Maarten Van Heemskerck's Rome: Antiquity, Memory, and the Cult of Ruins, Leiden and Boston, Brill, 2019.

Du Bellay, J., Le premier livre des Antiquitéz de Rome, Paris, Morel, 1558. Online: https:// gallica.bnf.fr/ark:/12148/bpt6k71123k/f4.image.

Echinger-Maurach, C., Studien zu Michelangelos Juliusgrabmal, Hildesheim, Olms, 1991.

Enenkel, K., 'The Species and Beyond: Early Modern Views on Classification and Generation, and their Theological, Ideological and Empirical Background', in: Enenkel, K., and P.J. Smith (eds.), Zoology in Early Modern Culture: Intersections of Science, Theology, Philology, and Political and Religious Education, Leiden, Brill, 2014, 57-148.

Ferriss-Hill, J., Horace's Ars Poetica: Family, Friendship, and the Art of Living, Princeton, NJ, Princeton University Press, 2019.

Findlen, P., Possessing Nature: Museums, Collecting and Scientific Culture in Early Modern Italy, Berkeley, University of California Press, 2010.

Fitch, J.G., 'Horace, Odes 1.3: Nature's Boundaries', Eranos 104 (2006-2007), 31-40.

Fitch, J.G., 'Nature in Horace', Green Letters: Studies in Ecocriticism 11.1 (2009), 28-29.

Freedman, L., Classical Myths in Italian Renaissance Painting, Cambridge and New York, Cambridge University Press, 2011. 
Freedman, L., 'Michelangelo's Reflections on Bacchus', Artibus et Historiae 24:47 (2003), 121-135.

Friis-Jensen, K., 'Commentaries on Horace's Art of Poetry in the Incunable Period', Renaissance Studies 9:2 (1995), 228-239.

Frommel, C.L., 'Cariatidi, telamoni e termini nelle Stanze di Raffaello', in: Frommel, S. (ed.), Construire avec le corps humain, ed. S. Frommel, 1:123-140.

Frommel, Sabine (ed.), Construire avec le corps humain: Les ordres anthropomorphes et leurs avatars dans l'art européen de l'antiquité à la fin du XVIe siècle, 2 vols., Rome, Campisano Editore, 2018.

Garnsey, P., Thinking about Property from Antiquity to the Age of Revolution, Cambridge and New York, Cambridge University Press. 2007.

Golden, L., 'Reception of Horace's Ars Poetica', in: Davis, G. (ed.), A Companion to Horace, New York, Wiley, 2010, 391-413.

Gombrich, E.H., The Sense of Order: A Study in the Psychology of Decorative Art, Ithaca, NY, Cornell University Press, 1979.

Guillaume, J., 'Hic Terminus Haeret: Du Terme d' Erasme à la Devise de Claude Gouffier: La Fortune d' un Emblème à La Renaissance', Journal of the Warburg and Courtauld Institutes 44 (1981), 186-192.

Hagstrum, Jean H., The Sister Arts: The Tradition of Literary Pictorialism and English Poetry from Dryden to Gray, Chicago, University of Chicago Press, $195^{8 .}$

Hansen, Maria F., The Art of Transformation: Grotesques in Sixteenth-Century Italy, Rome, Edizioni Quasar, 2018.

Harrison, Stephen, 'Town and Country', in: idem, The Cambridge Companion to Horace, Cambridge and New York, Cambridge University Press, 2007, 235-247.

Haskell, F., and N. Penny, Taste and the Antique: The Lure of Classical Sculpture 15001900, Turnhout, Miller, 2016.

Helas, Philine, ““... mit Blumen und duftenden Kräutern bedeckt”: Zur ephemeren Verwandlung Roms zwischen $145^{2}$ und 1513', in: Münch, B.U. (ed.), Von kurzer Dauer? Fallbeispiele zu temporären Kunstzentren der Vormoderne, Petersberg, Imhof, 2016, 57-75.

Hersey, G., The Lost Meaning of Classical Architecture, MIт Press, Cambridge, MA, 1998.

Hessler, C., Zum Paragone: Malerei, Skulptur und Dichtung in der Rangstreitkultur des Quattrocento, Berlin, de Gruyter, 2014.

Houghton, L.B.T., 'Renaissance and Golden Age Revisited: Virgil's Fourth Eclogue in Medici Florence', Bibliothèque d'Humanisme et Renaissance 76:3 (2014), 413-432.

Jacobs, F., '(Dis)Assembling: Marsyas, Michelangelo, and the Accademia del Disegno', The Art Bulletin 84:3 (2002), 426-448.

Johnson, C.D., Memory, Metaphor, and Aby Warburg's Atlas of Images, Ithaca, NY, Cornell University Press, 2012. 
Johnson, E.J., 'Portal of Empire and Wealth: Jacopo Sansovino's Entrance to the Venetian Mint', The Art Bulletin 86:3 (2004), 430-458.

Jones, R., and N. Penny, Raphael, New Haven and London, Yale University Press, 1987.

Joshel, S.R., Slavery in the Roman World, Cambridge and New York, Cambridge University Press, 2010.

Julien, P., 'Termes, atlantes, et caryatides: corps et decors d' une architecture discursive, XVIe-XviIIe siècles', in: Dekoninck, R., C. Heering, and M. Lefftz (eds.), Questions d'ornements, XVe-XVIIIe siècles, Turnhout, Brepols, 2013, 121-135.

Karafel, L., Raphael's Tapestries: The Grotesques of Leo X, New Haven, Yale University Press 2017.

Karmon, D., The Ruin of the Eternal City: Antiquity and Preservation in Renaissance Rome, Oxford and New York, Oxford University Press, 2011.

Kennedy, W.J., 'Humanist Classifications of Poetry Among the Arts and Sciences', in: Norton, G.P. (ed.), The Cambridge History of Literary Criticism: Volume 3, The Renaissance, Cambridge and New York, Cambridge University Press, 1989, 89-97.

Kommerell, V., Metamorphosed Margins: The Case for a Visual Rhetoric of the Renaissance Grottesche under the Influence of Ovid's Metamorphoses, Hildesheim, Georg Olms, 2008.

Laird, A., 'The Ars Poetica', in: Harrison, S.J. (ed.), The Cambridge Companion to Horace, Cambridge and New York, Cambridge University Press, 2007, 132-143.

Lazzaro, C., The Italian Renaissance Garden: From the Conventions of Planting, Design, and Ornament to the Grand Gardens of Sixteenth-Century Central Italy, New Haven and London, Yale University Press, 1990.

Levin, H., The Myth of the Golden Age in the Renaissance, Bloomington, Indiana University Press, 1969 .

Lomas, K. (ed.), Roman Italy, 338 BC-AD 200: A Sourcebook, London, Routledge, 2014.

Lovejoy, A.O., and G. Boas, Primitivism and Related Ideas in Antiquity, Baltimore, Johns Hopkins University Press, 1997.

Lowry, M., The World of Aldus Manutius: Business and Scholarship in Renaissance Venice, Ithaca, NY, Cornell University Press, 1979.

MacDougall, E.B., 'Ars Hortularum: Sixteenth-Century Garden Iconography and Literary Theory in Italy', in: Coffin, D. (ed.), The Italian Garden, Dumbarton Oaks, Washington, DC, 1972, 37-59.

MacDougall, E.B., Fountains, Statues, and Flowers: Studies in Italian Gardens of the Sixteenth and Seventeenth Centuries, Washington, DC, Dumbarton Oaks, 1994.

MacRae, M., Monsters \& Madness: The Drawings of Ulisse Aldrovandi (n.p., n.d.), Online: https://cvltnation.com/monsters-madness-the-drawings-of-ulisse-aldrovandi/.

Martelli, F., Ovid's Revisions: The Editor as Author, Cambridge and New York, Cambridge University Press, 2013. 
Miller, J.F., 'Ovid's Liberalia', in: Herbert-Brown, G. (ed.), Ovid's Fasti: Historical Readings at its Bimillennium, Oxford and New York, Oxford University Press, 2002, 199224.

Miller, P.A., Horace, London and New York, Tauris, 2019.

Morel, P., 'L' art des grotesques et les marges de la nature. L'hybride et le monstrueux entre science et imaginaire à la fin de la Renaissance', in: Olmi, G. et al. (eds.), NaturaCultura: L'interpretazione del mondo fisico nei testi e immagini, Florence, Olschki, 2002, 57-62.

Moss, A., 'Horace in the Sixteenth Century: Commentators into Critics', in: Norton, G.P. (ed.), The Cambridge History of Literary Criticism: Volume 3, The Renaissance, Cambridge and New York, Cambridge University Press, 1989, 66-76.

Nesselrath, A., 'Drei Zeichnungen von Marten van Heemskerck', in: von Hemming, V., and S. Schütze (eds.), Ars naturam adiuvans, Festschrift für Matthias Winner, Mainz, Von Zabern, 1996, 252-271.

Nichols, M.F., Author and Audience in Vitruvius' De architectura, Cambridge and New York, Cambridge University Press, 2017.

Nielsen, R.M., 'Virgil: Eclogue I', Latomus 31:1 (1972), 154-16o.

Osborne, R., 'The Erection and Mutilation of the Hermai', Proceedings of the Cambridge Philological Society, New Series 31 (1985), 47-73.

Otto, W.F., Dionysus: Myth and Cult, Bloomington, Indiana University Press, 1965.

Panofsky E., 'Et in Arcadia Ego: Poussin and the Elegiac Tradition', in: idem, Meaning in the Visual Arts, Garden City, NY, Doubleday, 1955, 295-320.

Parker, H.C., 'Romani Numen Soli: Faunus in Ovid's Fasti', Transactions of the American Philological Association 123 (1993), 199-217.

Payne, A.A., 'Mescolare, composti and Monsters in Italian Architectural Theory of the Renaissance', in: Secchi Tarugi, L. (ed.), Disarmonia bruttezza e bizzarria nel Rinascimento, Luisa Florence, Cesati, 1998, 274-294.

Platner, S.B., and T. Ashby, A Topographical Dictionary of Ancient Rome, London, Oxford University Press, 1929, Online: https://penelope.uchicago.edu/Thayer/E/Gazetteer/ Places/Europe/Italy/Lazio/Roma/Rome/_Texts/PLATOP*/T.html.

Platt, V.J., Facing the Gods: Epiphany and Representation in Graeco-Roman Art, Literature and Religion, Cambridge and New York, Cambridge University Press, 2011.

Plommer, H., 'Vitruvius and the Origin of Caryatids', The Journal of Hellenic Studies 99 (1979), 97-102.

Porter, D.H., Horace's Poetic Journey: A Reading of Odes 1-3, Princeton, NJ, Princeton University Press, 2014.

Quinn, J.C., 'Herms, Kouroi, and the Political Anatomy of Athens', Greece \& Rome 54:1 (2007), 82-105.

Robert, J., 'Pan', in: Moog-Grünewald, M., et al. (eds.), Brill's New Pauly, Supplements, 4: The Reception of Myth and Mythology, Leiden, Brill, 2010, 496. 
Rowlands, J., 'Terminus, the Device of Erasmus of Rotterdam: A Painting by Holbein', Bulletin of the Cleveland Museum of Art 68:2 (1980), 50-54.

Rubinstein, N., 'Youth and Spring in Botticelli's Primavera', Journal of the Warburg and Courtauld Institutes 6o (1997), 248-251.

Rudd, N. (ed.), Horace, Epistles, Book II and Epistle to the Pisones ('Ars poetica'), Cambridge and New York, Cambridge University Press, 1989.

Russell, D., 'Wives and Widows: The Emblematics of Marriage and Mourning in France at the End of the Renaissance', in: Saunders, A.M., and P. Davidson (eds.), Visual Words and Verbal Pictures: Essays in Honour of Michael Bath, Geneva, Droz, 2005, 141-16o.

Rykwert, J., The Dancing Column: On Order in Architecture, Cambridge, MA, MIT Press, 1999.

Rykwert, J., The Idea of a Town: The Anthropology of Urban Form in Rome, Italy and the Ancient World, London, Faber \& Faber, 1976.

Schmitt, L., Der Siegelring des Erasmus von Rotterdam: auf den Spuren eines Rätsels der Renaissancezeit, Basel, Baumann, 2009, Online: https://www.hmb.ch/fileadmin/a/ $\mathrm{hmb} /$ dateien/pdf/basler-kostbarkeiten/HMB-3o-Der-Siegelring-des-Erasmus-von -Rotterdam.pdf.

Sher, S.K. (ed.), The Currency of Fame: Portrait Medals of the Renaissance, New York, Abrams, 1994.

Silver, L., The Paintings of Quinten Massys, with Catalogue Raisonné, Oxford, Phaidon, 1984.

Stinger, C.L., The Renaissance in Rome, Bloomington, Indiana University Press, 1998.

Thomas, R.F., 'The Landscapes of Horace', in: idem (ed.), Lands and Peoples in Roman Poetry: The Ethnographical Tradition, Cambridge, Cambridge Philological Society, 1982, 8-34.

Van Loyen, U., and G. Regn, 'Dionysus', in: Moog-Grünewald, M., et al. (eds.), Brill's New Pauly, Supplements 4: The Reception of Myth and Mythology, Leiden, Brill, 2010, 240. Vredeveld, H., 'Introduction' to Collected Works of Desiderius Erasmus:Poems, translated by C. Miller, Toronto, University of Toronto Press, 1993, xxx-I.

Watson, P.F., 'On a Window in Parnassus', Artibus et Historiae 8:16 (1987), 127-148.

Weil-Garris Posner, K., 'On Pedestals: Michelangelo's David, Bandinelli's Hercules and Cacus and the Sculpture of the Piazza della Signoria', Römisches Jahrbuch für Kunstgeschichte 20 (1983), 377-415.

Wendt, C., 'Xerxes am Tay, oder “Bedenke, Du bist nur ein Mensch"', in: Kopp, H., and C. Wendt (eds.), Thalassokratographie: Rezeption und Transformation antiker Seeherrschaft, Berlin, de Gruyter, 2018, 61-9o.

Williams, R., Raphael and the Redefinition of Art in Renaissance Italy, Cambridge and New York, Cambridge University Press, 2017.

Wiseman, T.P., The Myths of Rome, Exeter, University of Exeter Press, 2004. 
Woodard, R.D., 'The Disruption of Time in Myth and Epic', Arethusa 35:1 (2002), 83-98. Wright, A., '“... con uno inbasamento et ornamento alto": The Rhetoric of the Pedestal c. 1430-1550', Art History 34:1 (2011), 8-53.

Zamperini, A., Ornament and the Grotesque: Fantastical Decoration from Antiquity to Art Nouveau, London and New York, Thames \& Hudson, 2008.

Zorzi, N., 'Hesiod in the Byzantine and Early Renaissance Periods', in: Loney, A.C., and S. Scully (eds.), The Oxford Handbook of Hesiod, Oxford and New York, Oxford University Press, 2018, 413-430.

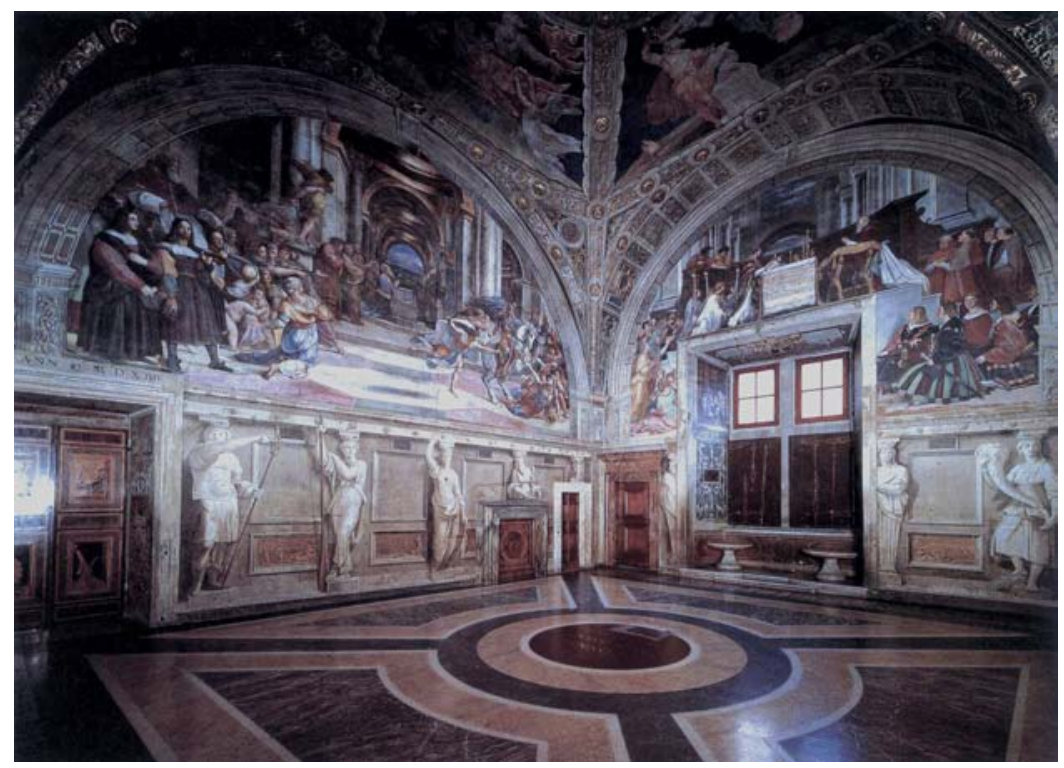

FIGURE 1 Raphael and Workshop, Stanza d'Eliodoro, General View: Expulsion of Heliodorus from the Temple and Mass of Bolsena, Dado with Support Figures (Terms under Window)

PHOTO ORO1, PUBLIC DOMAIN. CC BY-SA 3.O, WIKIMEDIA COMMONS 


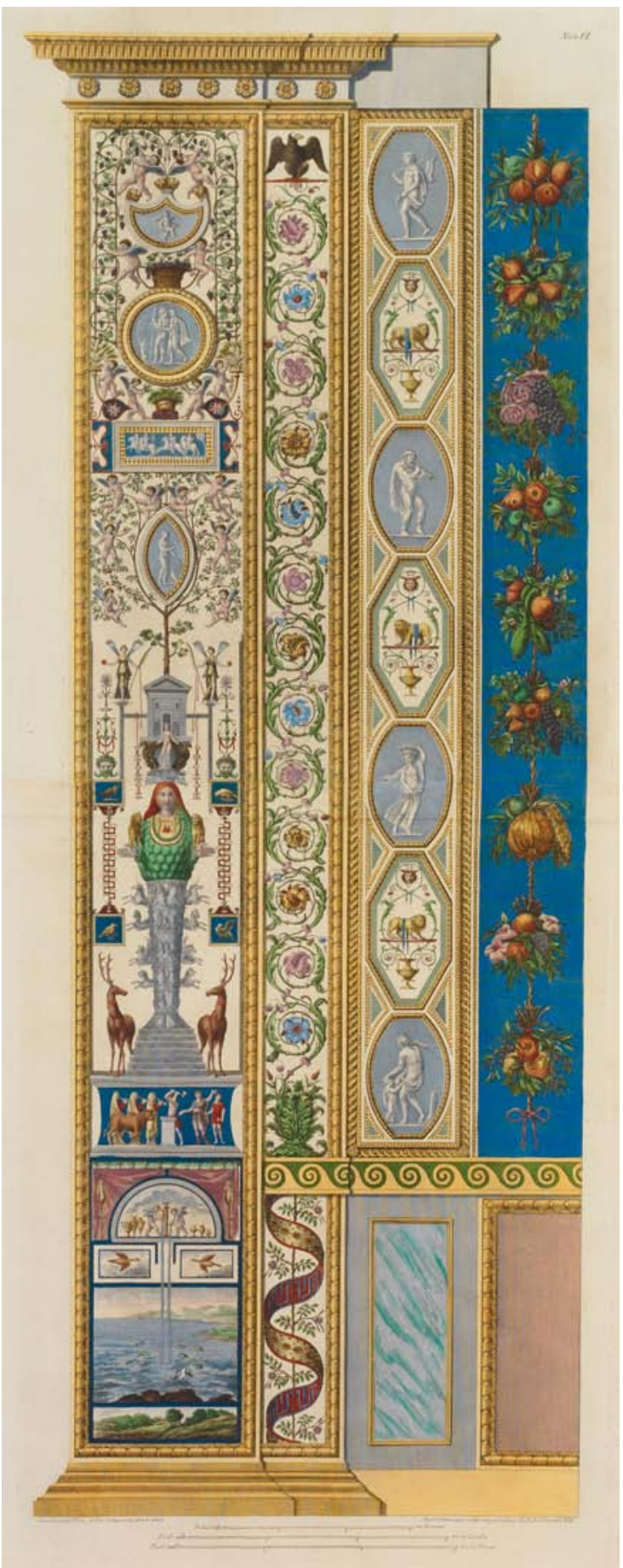

FIGURE 2

Giovanni Ottaviani, Colored Engraving of Grotesque Ornament in the Loggia of Raphael, Sheet no. 6 of the Series (Rome 1772-1776). Note the 'term' of many-breasted Diana (as personification of Nature) supporting miniature building on her head PHOTO MICHAEL ZELLER, WIKIMEDIA COMMONS 


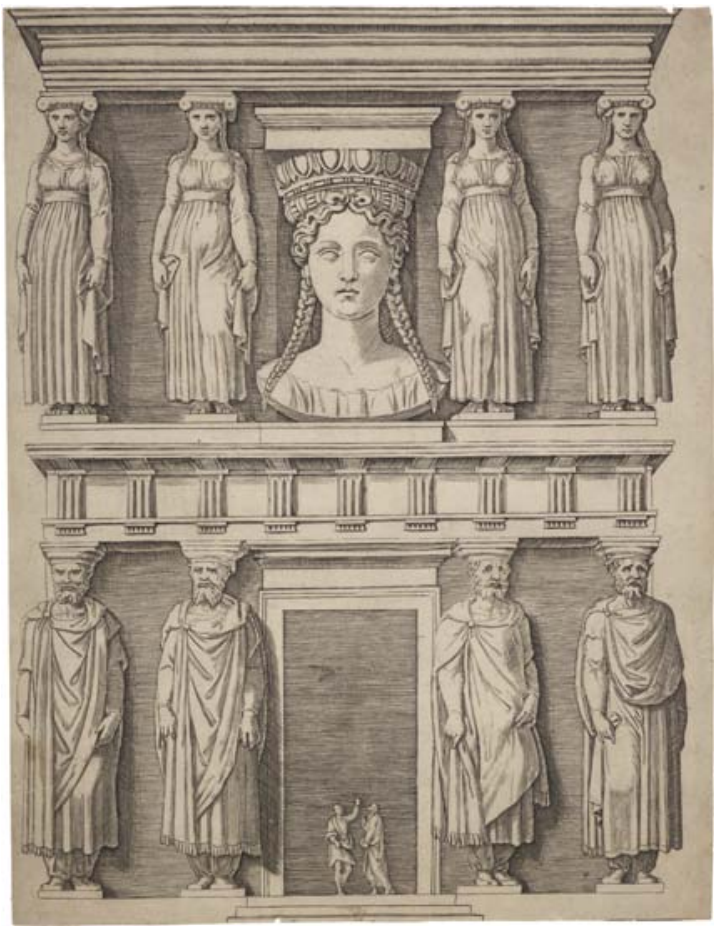

FIGURE 3

After Raphael, Facade with Caryatids (c. 1520) ENGRAVING BY MARCANTONIO RAIMONDI, MUSEUM OF NEW ZEALAND/TE PAPA, ACQUIRED 2015 (2015-OO565). CC BY-NC-ND

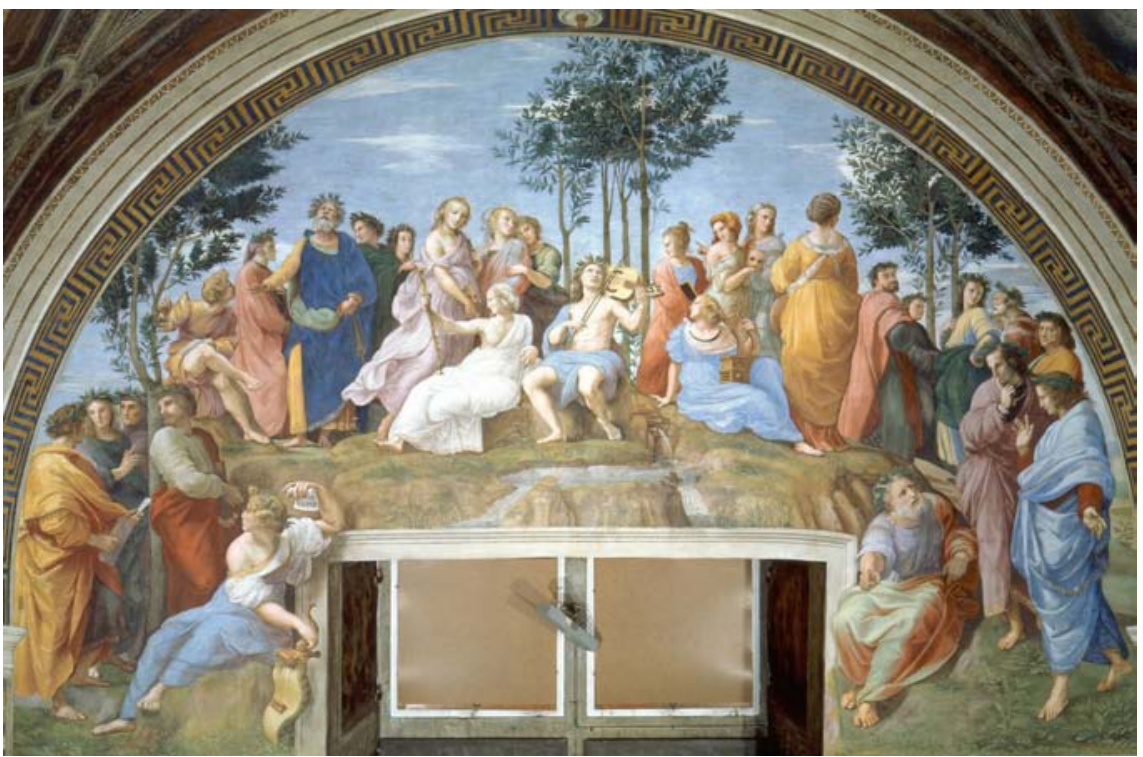

FIGURE 4 Raphael, Mount Parnassus, fresco. North wall, Stanza della Segnatura, Vatican. In the sixteenth century, the window opened to a view of the Belvedere Garden WIKIMEDIA COMMONS 


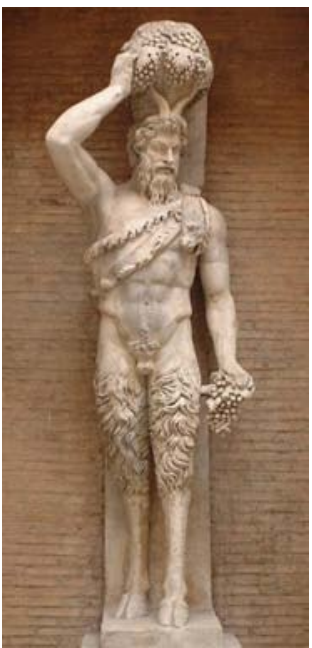

FIGURE 5

One of two Satyrs from the Della Valle collection, Capitoline Museums, Rome. Inventory No. MCOOO4 PHOTO MARIE-LAN NGUYEN, WIKIMEDIA COMMONS

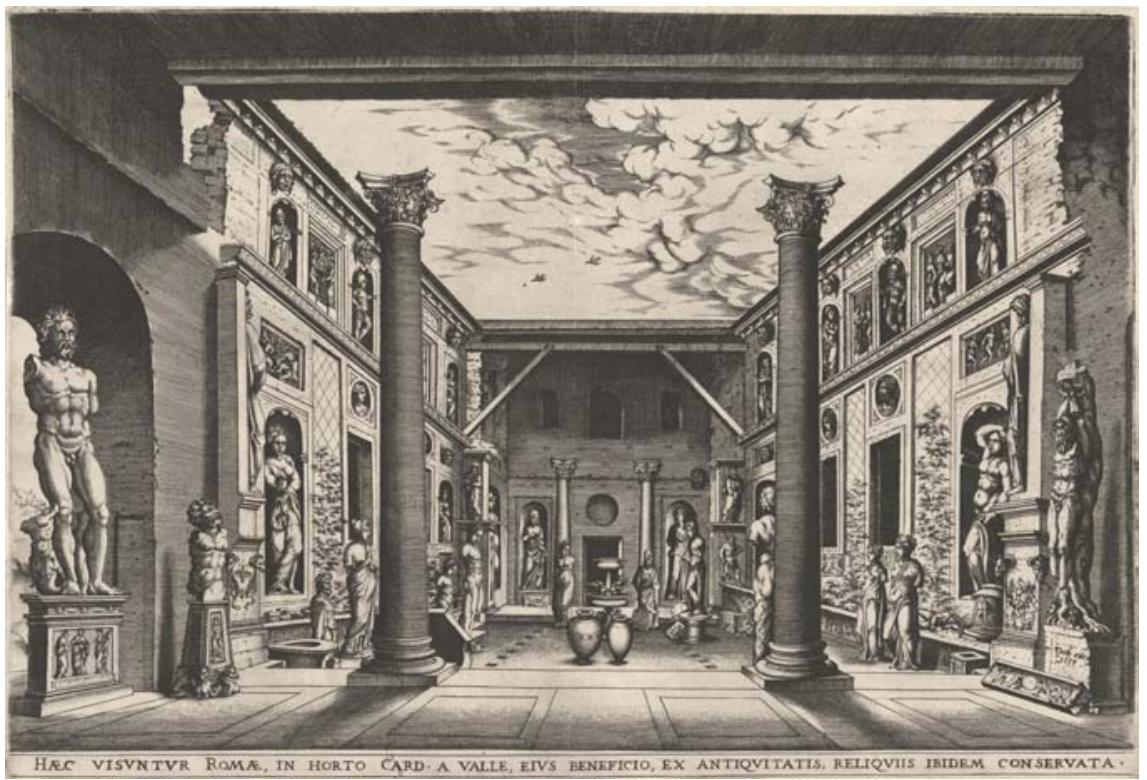

FIGURE 6 Maarten van Heemskerck (after), Courtyard of the Palazzo Valle-Capranica with Statues of Satyrs (1533). Engraving by Jan or Lucas van Deutecum or Doetchum. Kupferstichkabinett, Staatliche Museen, Berlin, Germany, Inventory No. New Hollstein, 599

PHOTO: JÖRG P. ANDERS. ART RESOURCE, NY, ART454592 


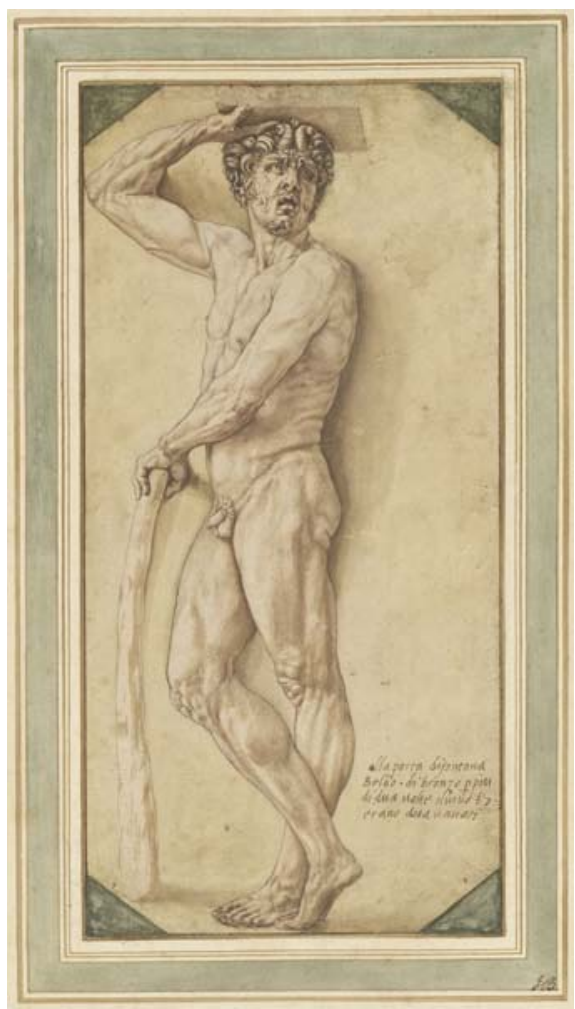

Satyri figura altera cum tuba.

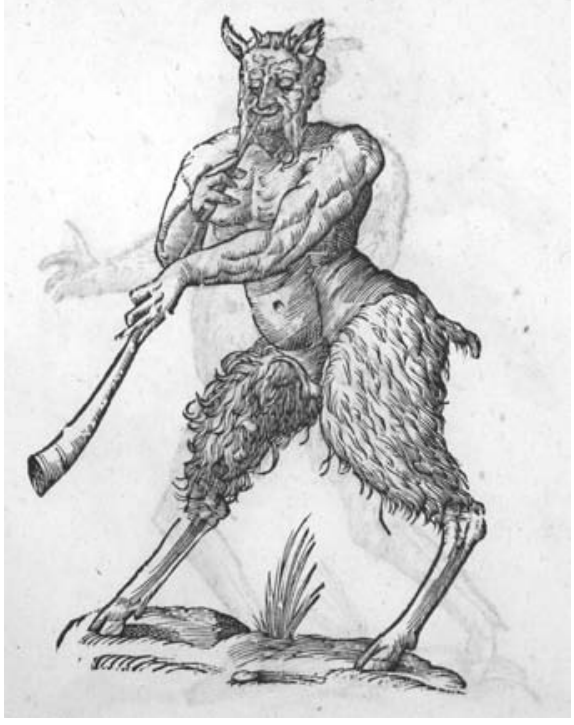

FIGURE 7

Benvenuto Cellini, Satyr, drawing (1544/ 1545). Pen and brown ink with brown wash over black chalk. Design for one of two satyrs (recognizable by their ears) intended to frame the Porte Dorée at Fontainebleau Palace

NATIONAL GALLERY OF ART, WOODNER COLLECTION, PATRONS' PERMANENT FUND, INVENTORY NO. 1991.19O.2. CREATIVE COMMONS CCO 1.0

FIGURE 8

Jean-Baptiste Coriolan, Satyr, in Ulisse Androvandi, Monstrorum historia (1642), p. 24 COURTESY HISTORY OF SCIENCE COLLECTIONS, UNIVERSITY OF OKLAHOMA LIBRARIES. WIKIMEDIA COMMONS 


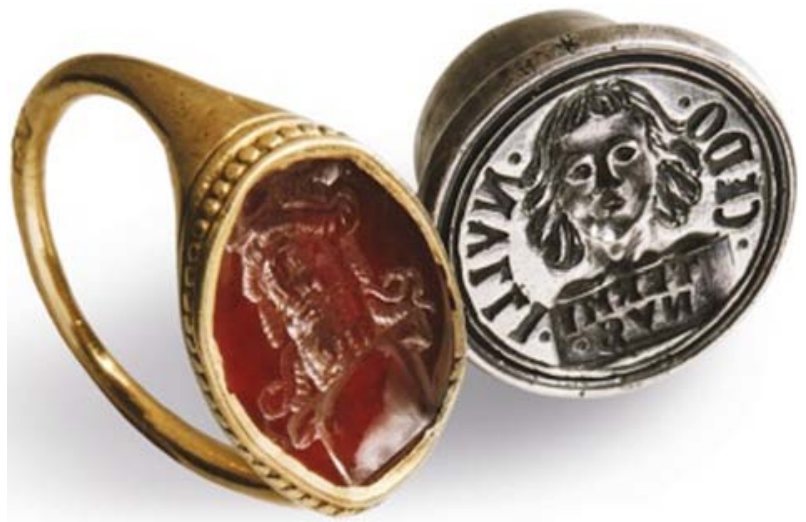

FIGURE 9 Antique ring with engraved Carnelian once owned by Erasmus (left), with image of Dionysus identified by Erasmus as Terminus, Historisches Museum, Basel No. 1893-365; Right: Erasmus's seal punch with image of youthful Terminus, Historisches Museum, Basel No. $1893-364$ COURTESY HISTORISCHES MUSEUM, BASEL. PHOTO P. PORTNER

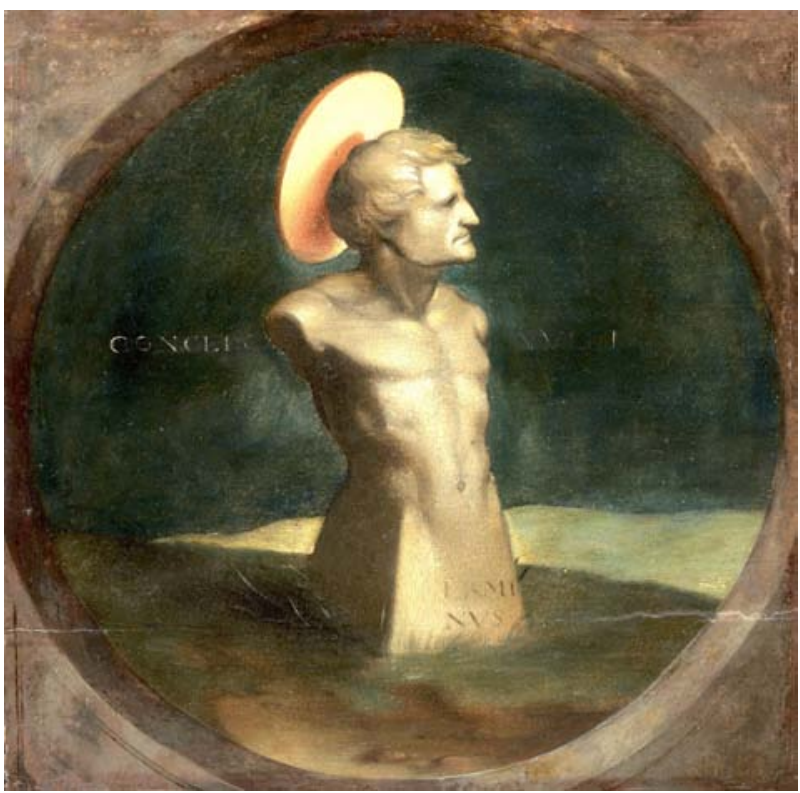

FIGURE 10 Holbein (attr.), Terminus, the Emblem of Erasmus, oil on wood, c. 1532

CLEVELAND MUSEUM OF ART, INVENTORY NUMBER, 1971.166. EN.WIKIPEDIA.ORG. CMA CCO 

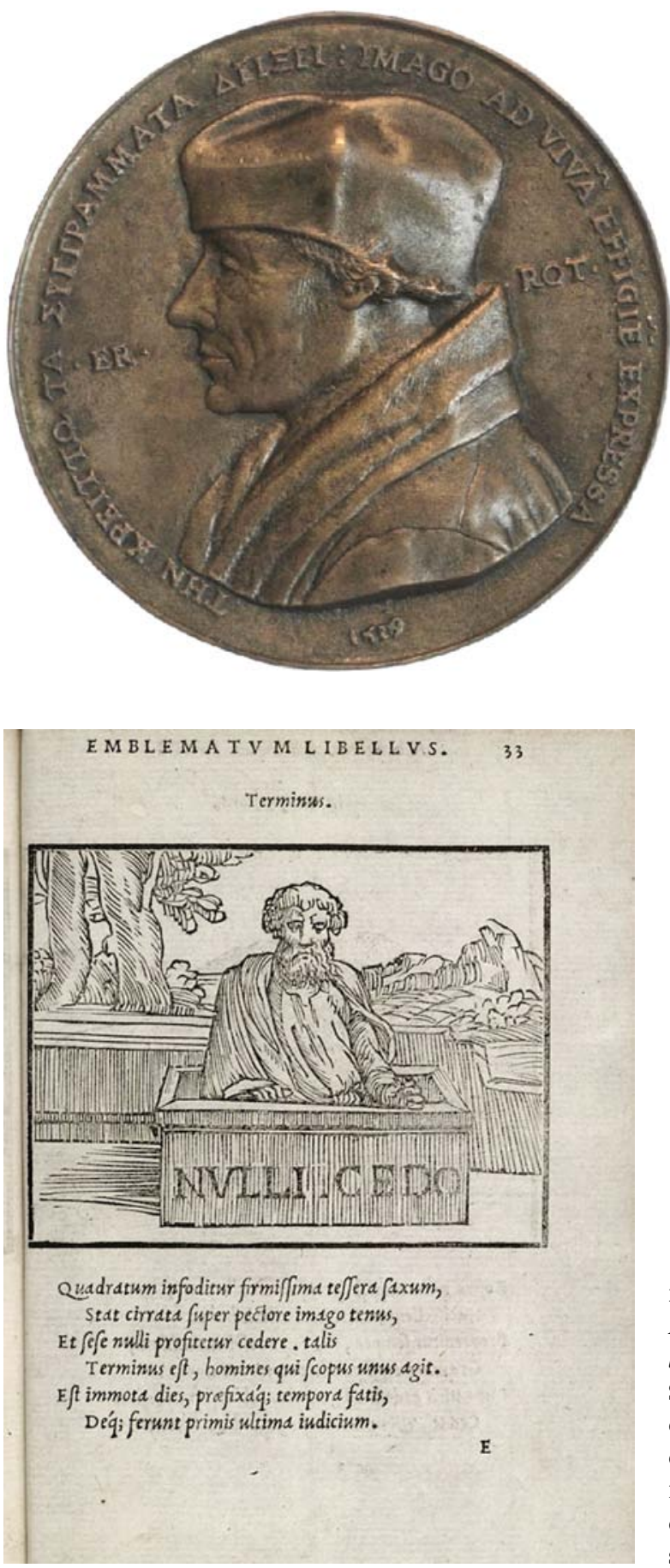

FIGURE 11

Quentin Metsys or

Massys, Medallion for

Desiderius Erasmus (15171519). Obverse, portrait of Erasmus; Reverse, image of Terminus

FITZWILLIAM MUSEUM, CAMBRIDGE. INVENTORY NO. CM.193-1969

\section{FIGURE 12}

Andrea Alciato, Emblematum libellus (Venice 1546), No. 33 . Stirling Maxwell Collection COURTESY OF THE ARCHIVES \& SPECIAL COLLECTIONS, UNIVERSITY OF GLASGOW LIBRARY, GUL SM 29 A1R 

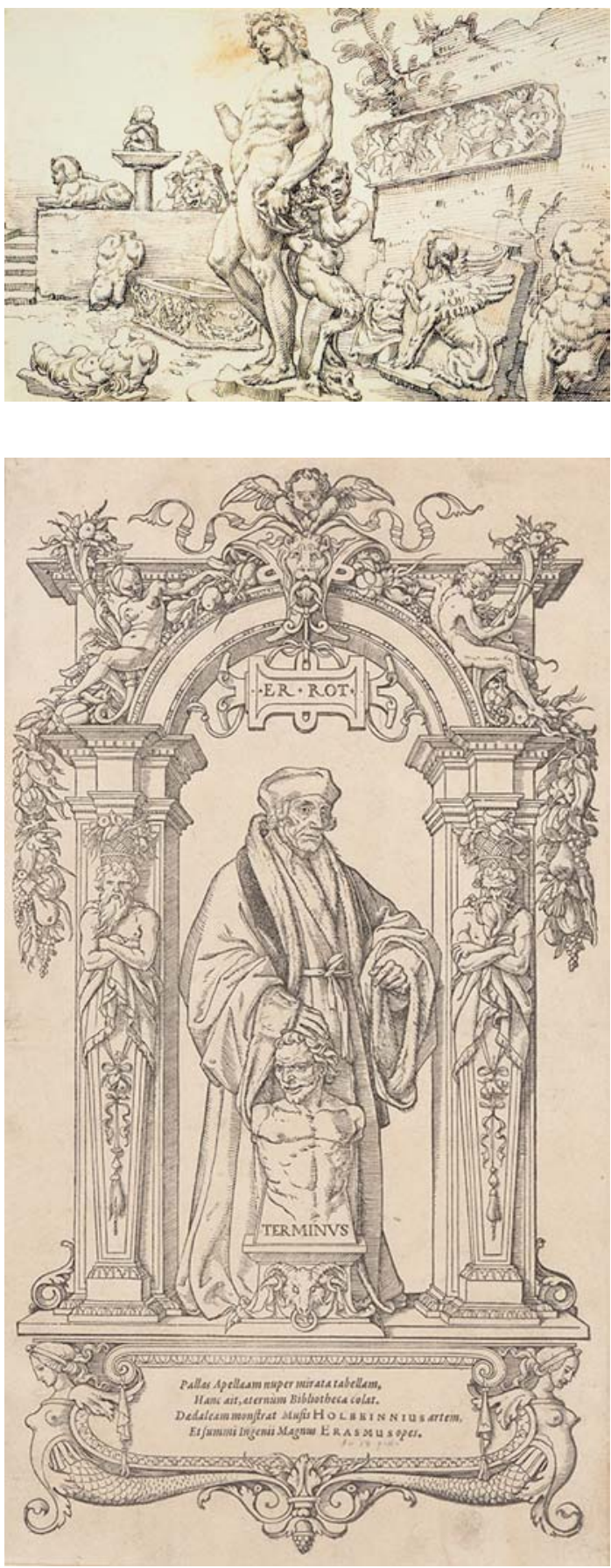

FIGURE 13

Maarten van Heemskerck, The Garden in the Casa Galli, with Michelangelo's statue of Bacchus (c. 1532-1536). From the Roman Sketchbook I. Pen and brown ink, brown wash. Kupferstichkabinett, Staatliche Museen, Berlin, Germany

PHOTO BY JOERG P. ANDERS, ART RESOURCE, NY, ART391036

FIGURE 14

Han Holbein the Younger (after), Portrait of Erasmus of Rotterdam with Terminus (1535-1538). Woodcut, Second State. Davison Art Center, Wesleyan University, Inventory No. 1940.D1.123. Gift of George W. Davison, 1940 PHOTO R. LEE. OPEN ACCESS IMAGE FROM THE DAVISON ART CENTER 